\title{
AMERICAN SKIN: DISPENSING WITH COLORBLINDNESS AND CRITICAL MASS IN AFFIRMATIVE ACTION
}

\author{
Deirdre M. Bowen ${ }^{*}$
}

\begin{abstract}
This exploratory empirical work examines whether students of color enjoy the benefits articulated by the U.S. Supreme Court in Grutter v. Bollinger, which rationalized the continuation of affirmative action based on diversity interests. Specifically, the Court stated that affirmative action was permissible because students of all backgrounds would increase their racial understanding and decrease their racial stereotyping of minorities. Neither side was happy with the decision, and both were skeptical that such benefits could transpire for minority students. Yet in the heat of continuing debate, neither group has empirical support for their arguments until now.
\end{abstract}

Using survey data of over 370 under-represented minority students majoring in the sciences from twenty-eight states, this article provides insight into whether students of color have, first, increased their racial understanding and, second, experienced a decrease in stigma associated with racial stereotyping since Grutter. The first part of the study asks whether minority students enjoy these benefits when they are learning with others whose racial or ethnic backgrounds are different from

\footnotetext{
* Deirdre M. Bowen is an associate professor of lawyering skills at Seattle University. This article was supported in part by Grant No. U54 DE019346 from the National Institute of Dental and Craniofacial Research, NIH. Many people deserve thanks in assisting me with this work. At the top of the list is my social science research assistant, Sasha Craft, for her excellent data collection skills and my legal research assistant, Jes Erickson, for her patience and dedication in managing the many revisions. Thanks to Richard Delgado, andré douglas pond cummings, Robin Lenhardt, and Sheila Foster for reading or discussing earlier drafts. A debt of gratitude goes to Roberta Furst, Sarah Gallagher, and Patricia Sully for their assistance. As always, Dr. Peter Milgrom's support is beyond repayment. Finally, a huge thankyou to the students who were willing to share their thoughts on the survey and who trusted that I would do the right thing.
} 
U N I V E R S I T Y O F P I T T S B U R G H L A W R E V I E W

PAGE

their own and whether the benefits vary depending on a student's attendance in an affirmative action institution.

Part two of the study analyzes whether these same benefits accrue when students are in a "critical mass" environment in which other members of their same racial and ethnic background are also present in the classroom. As a key component of Grutter's rationale was that affirmative action created the much-needed critical mass of minority students, the second element of the study seeks to answer two questions: First, what, if any, benefits emerge when critical mass is present in the classroom, and second, how do these benefits differ for students in affirmative action versus anti-affirmative action institutions?

In considering the first Grutter benefit - an increase in racial understanding when learning in a diverse environment - the results are generally encouraging. Most minority students report this benefit emerges in a diverse classroom. Unfortunately, the second Grutter benefit-decreased racial stereotypingmaterializes infrequently in a diverse class. Less than a third of students report a decrease in stigma associated with a reduction in racial stereotyping. Remarkably, these results do not vary based on the presence of an affirmative action program.

Affirmative action, however, did play a role when determining whether the Grutter benefits emerged under conditions of critical mass. Students in affirmative action institutions were more likely to report experiencing both Grutter benefits at greater rates than students in anti-affirmative action institutions. Alarmingly, even with affirmative action and critical mass, only about a third of students encountered the benefits of increased racial understanding and decreased racial stereotyping.

The paper argues that these troubling results are the result of creating the landscape of diversity in a "post-race" topography. I argue that affirmative action is a vibrant and necessary tool towards reaching the Grutter goals, but institutions of higher learning must first dispense with the paradox of diversity in a colorblind world. Step one: reincarnate race consciousness. Step two: abandon the critical mass concept.

\section{INTRODUCTION}

"The desire for a racially diverse community, particularly a diverse school community, is, like the desire for romance, attractive to consider in the abstract. . . . [However,] [r] eality is the enemy of romance." I

\footnotetext{
${ }^{1}$ Derrick Bell, What's Diversity Got to Do with It?, 6 SEATTLE J. FOR Soc. JUST. 527, 527 (2008).
} 
Numerous schools tout diversity in their glossy lookbooks, websites, and admissions packets, but further examination of the materials, the actual percentage of minorities in the campus population, or both, reveals little as to why the school prioritizes a diverse student body. ${ }^{2}$

The new affirmative action paradigm focuses on the benefits of diversity for all students, unlike in the past where the short-lived focus was on redressing past discrimination. ${ }^{3}$ The Court held in Grutter v. Bollinger that the University of Michigan Law School had a compelling state interest in preparing its students for an increasingly diverse work force and society by promoting cross-racial understanding and breaking down racial stereotypes. ${ }^{4}$ However, both proponents and opponents of affirmative action viewed with skepticism the Court's adoption of the affirmative action diversity paradigm. Opponents and supporters of diversity articulated dire predictions about what student diversity via affirmative action would offer. ${ }^{5}$ Opponents asserted that diversity affirmative action would ultimately take the form of thinly disguised quotas, and supporters worried about tokenism. The question remains, though, how a "diverse student body" rationale benefits or harms students who are the diversity-i.e., students of color. I seek to empirically answer that question in this article.

My research presents the first examination of the post-Grutter cohorts' perceptions of the benefits of diversity. I hope to provide insight into how students of color-a group for whom both opponents and proponents profess concern in the affirmative action debate-fare under the Grutter Court's race-neutral model of

2 See, e.g., Minorities in College Leveling Off, WASH. TIMES, Oct. 9, 2008, http://www.washingtontimes.com/news/2008/oct/09/minorities-in-college-leveling-despite-rise/; Jerry Crimmins, Law Deans Stress Need for Pipeline to Improve Diversity, CHI. DAILY L. BuLL., Feb. 11, 2010, available at http://www.luc.edu/ law/news/pdfs/dean_yellen_pipeline.pdf.

${ }^{3}$ The diversity paradigm first appeared in Regents of the Univ. of Cal. v. Bakke, 438 U.S. 265 (1978). The U.S. Supreme Court contemplated whether U.C. Davis Medical School violated the Equal Protection Clause of the Constitution by setting aside sixteen seats for racial minority applicants. With a four/four split, Powell cast the deciding vote. His decision struck down the medical school's admissions plan because it relied too heavily on race instead of considering it as one of many types of factors that measure diversity. However, Powell articulated only his own thoughts that "the attainment of a diverse student body . . . clearly is a constitutionally permissible goal for an institution of higher learning." Id. at 311-12. While the diversity paradigm was introduced in Bakke, it did not replace the remedial paradigm until Grutter, as will be discussed infra in Part III.

4539 U.S. 306 (2003).

${ }^{5}$ See infra Part IV.C. for a full discussion. 
U N I V E R S I T Y O F P I T T S B U R G H L A W R E V I E W

PAGE

diversity. ${ }^{6}$ My goal is to factually interrogate some of the predictions that opponents and proponents made in the wake of the diversity model of affirmative action.

This study adds insight to the debate about the appropriateness of diversity and, specifically, critical mass as rationales for maintaining affirmative action. It has been eight years since the Supreme Court issued its twin decisions of Grutter and $\mathrm{Gratz}^{7}$ and six years since institutions of higher learning adjusted their admissions plans to comport with the new "forward looking" diversity model of affirmative action-long enough for a university's transformed student body to reflect on the alleged harms and benefits of diversity. ${ }^{8}$ Using empirical data collected in November 2009 from a national sample of 372 under-represented minority undergraduate students majoring in the sciences, this article offers a first look at how affirmative action as a diversity model operates for the population of students defined as diverse.

Moreover, it seeks to answer Justice O'Connor's recent call for more research. ${ }^{9}$ The paper examines two questions. First, has affirmative action achieved the benefits set out in Grutter of increased cross-racial understanding and decreased racial stereotyping? In short, the majority of under-represented students of color do report increased racial understanding in a diverse classroom. However, increased racial understanding does not necessarily translate into achieving Grutter's second goal of decreased racial stereotyping. Less than a third of minority students present in a diverse classroom report a decrease in the stigma associated with eradicating racial stereotyping.

\footnotetext{
${ }^{6}$ By using the term "race neutral," I am referring to the types of benefits that all racial groups should enjoy, allegedly, such as increased learning, motivation, greater understanding of other racial groups, and increased contact with other students from different racial and ethnic groups.

${ }^{7}$ Gratz v. Bollinger, 539 U.S. 244 (2003).

${ }^{8}$ As the Supreme Court issued these decisions in July 2003, one can presume that college admissions offices did not make changes in their policies until the incoming class of 2004, which would have graduated between June 2008-2010. It takes many students an average of four to six years to complete a college degree. See Carol Frey, Different Paths to a College Degree, U.S. NEWS \& WoRLD REP., Sept. 1, 2009, at 40, available at http://www.usnews.com/articles/education/ bestcolleges/2009/08/19/different-paths-to-a-college-degree.html.

9 Justice O'Connor recently co-authored an essay in which she called for research, debate, and innovation. See Sandra Day O'Connor \& Stewart Schwab, Affirmative Action in Higher Education over the Next Twenty-five Years: A Need for Study and Action, in The NeXt 25 Years: AfFirmative Action in Higher Education in the United States and South Africa 58 (David L. Featherman, Martin Hall \& Marvin Krislov eds., 2010).
} 
The second component of this first question asks whether these benefits, however incremental, differ when affirmative action is added to the equation of a diverse classroom. Students who report both a decrease in stigma associated with racial stereotyping and an increase in racial understanding do not differ in their responses based on whether they attend an affirmative action institution.

At first glance, these results suggest the failure of affirmative action. But a more nuanced look at the data is required. This question focuses solely on a diverse classroom. Remember, students of color, regardless of where they attend school, are more likely to find themselves in a diverse classroom. In fact, underrepresented students of color have, for most of their educational careers, been in classrooms that consistently provide the opportunity to improve their own racial understanding. However, Grutter rationalized affirmative action as providing race neutral benefits. The concern, then, may be that diverse settings alone do not guarantee that white students in the class will increase their cross-racial understanding and decrease racial stereotyping of minority students. ${ }^{10}$ That is why the linchpin of affirmative action was its ability to go beyond diversity and fashion critical mass.

Hence, the second question gets to the central theme of this study. How does critical mass affect minority students' perceptions of the Grutter benefits, and how does affirmative action play a role in their realization? Because students in affirmative action states were more likely to report decreased stigma from racial stereotyping and an increase in racial understanding than students in antiaffirmative action states, the data suggest an important caveat. Diverse classrooms actually require meaningful critical mass, and affirmative action may facilitate the latter. ${ }^{11}$ After all, as the Michigan Law School argued in Grutter, a key ingredient of affirmative action's effectiveness is critical mass. ${ }^{12}$

Thus, it might be possible that students in affirmative action institutions are experiencing decreased stigma at greater rates than their counterparts in anti-

\footnotetext{
${ }^{10}$ As Patricia Gurin found in her study used in the Grutter case, minority students tended to have greater cross-racial understanding than white students because such students are more likely to be in a diverse classroom throughout their educational careers compared to white students. See Expert Witness Report of Patricia Gurin, Grutter v. Bollinger, 137 F. Supp. 2d 821 (E.D. Mich. 2001) (No. 97-75928), reprinted in Expert Report of Patricia Gurin, 5 MICH. J. RACE \& L. 363, 372-73, 390 (1999).

${ }^{11}$ The caveat is extremely important. As noted earlier, two-thirds of students do not report experiencing the benefit of decreased stigma, most likely because they do not find themselves in classrooms that create a critical mass of diverse students. See Grutter v. Bollinger, 539 U.S. 306, 318 (2003) (discussing the testimony of Erica Munzel, the Director of Admissions at the law school).

${ }^{12}$ Id.
} 
affirmative action institutions because the affirmative action institutions' student bodies possess more than diversity. They may craft critical mass diversity. ${ }^{13}$ "Critical mass diversity" refers to a concentration of students of a particular ethnic or racial background in the classroom such that others are able to see the variety of experiences and viewpoints that students in that racial or ethnic group hold. In addition, critical mass offers students in that racial group an opportunity to get beyond tokenism and no longer sense their presence in the classroom as the spokesperson for their race or ethnicity.

A quick reading of these particular results may inspire a cause for celebration. Again, restraint is urged in favor of nuance. It is not affirmative action alone that creates the benefits. It is a specific type of classroom diversity, i.e., meaningful critical mass that could encourage the Grutter benefits. To state it plainly, affirmative action simply creates the opportunity for meaningful critical mass to occur in the classroom. However, embedded in the concept of critical mass is the idea that it initiates functional diversity. ${ }^{14}$

Critical mass may well set the stage for functional diversity, but I conclude in this study that institutional over-reliance on it may actually stymie the emergence of affirmative action benefits. Add the discourse of colorblindness to the setting, and the benefits are probably significantly thwarted. My pessimism comes from the fact that only about one-third of minority students actualized these benefits in the critical mass classroom of affirmative action institutions. In anti-affirmative action states, the derisory rate was one-fifth.

Hence, I am compelled to argue that institutions of higher learning should let the concept of critical mass dissipate and reignite color consciousness.

The results of the study invite controversy. A quick read of the results can lead to a conclusion that affirmative action makes no difference for the majority of students of color in terms of achieving Grutter benefits. ${ }^{15}$ While the antiaffirmative action camp may embrace this shortsighted inference in support of its

\footnotetext{
${ }^{13}$ See Deirdre M. Bowen, Brilliant Disguise: An Empirical Analysis of a Social Experiment Banning Affirmative Action, 85 IND. L.J. 1197 (2010) (finding that students in affirmative action states were much less racially isolated and much less likely to experience stigma and racial hostility).

${ }^{14}$ Functional diversity allows for "(1) inclusion; (2) social meaning; (3) citizenship; (4) belonging; (5) colorblindness; (6) speech; and (7) institutional culture. Each function derives from the relationship between race and social experiences." Devon W. Carbado \& Mitu Gulati, What Exactly is Racial Diversity?, 91 CALIF. L. REV. 1149, 1154 (2003) (book review).

15 Recall that these benefits are twofold: increased racial understanding and decreased racial stereotyping. Grutter, 539 U.S. at 308.
} 
notion that diversity is, at best, window dressing and, at worst, a vaguely disguised quota system in violation of the Equal Protection Clause, such a claim ignores what could be possible with affirmative action.

On the other hand, supporters of affirmative action must also examine the limits of critical mass diversity as a concept. We must demand institutions of higher learning to do more to bring into fruition the benefits of diversity for all students. The cautionary tale in this study is that the diversity model of affirmative action is still a work in progress. In reaching critical mass, affirmative action can play an essential role in setting the stage to transform the mindset of diversity consumers. ${ }^{16}$ However, a cultural shift away from post-race and critical mass dependence will give rise to functional diversity: to create a kind of racial understanding that eliminates stigma caused by racial stereotyping. ${ }^{17}$

Part II of this article briefly explores the legal and social-scientific definitions, criticisms, and benefits of the diversity paradigm. Part III explains the methodology employed to conduct this study. Part IV examines the results. This section is organized into four components. First, it presents the entire sample's perceptions of encountering the Grutter benefits while learning in a diverse environment. The second section then explores this question more deeply by comparing the perceptions of students who attended affirmative action institutions with those of students who attended anti-affirmative action institutions. In section three, I return to the results of the entire sample but examine the crucial question of how critical mass in the classroom affects the emergence of the Grutter benefits. Finally, the last section addresses the fundamental question by interrogating how critical mass intersects with the type of institution a student attends. Are affirmative action students in critical mass classrooms the most likely to report the incidence of increased racial understanding and decreased racial stereotyping?

Part V discusses the implications of these results. I specifically argue that the diversity model of affirmative action is a work in progress. It is not yet meaningful for a majority of students of color. I argue that affirmative action allows for the possibility of critical mass. However, critical mass only sets the stage for the

\footnotetext{
${ }^{16}$ Delgado warned long ago that the greatest danger for minorities was the dominant group's mindset. See Richard Delgado, Storytelling for Oppositionists and Others: A Plea for Narrative, 87 MicH. L. REV. 2411, 2413-14, 2441 (1989). In the current context, the dominant group demands that students of color rationalize their presence on campus to enhance the current curriculum of the dominant group. Yet, the dominant group's presence on campus is taken for granted. Requiring students of color to justify their existence reinforces the mindset of interlopers versus proprietors of that space.

${ }^{17}$ I caution the reader at the outset that this study is exploratory in nature. Therefore, it seeks to provide some insight but it also raises more questions via theoretical explanations than definitive answers.
} 
essential part of the challenge. In the end, the concept of critical mass may be irrelevant. A far more imperative goal is for institutions of higher learning to annihilate the paradox of manufacturing diverse classrooms while operating in a mythical colorblind society. I conclude that without moving beyond critical mass towards color consciousness, the Grutter goals of diversity are rendered dysfunctional. ${ }^{18}$ Finally, I offer recommendations for the future of diversity in higher education. I suggest what I call a "Contextualized Social Contingencies" model, in which we use a vibrant model of affirmative action to explore color consciousness and then learn from it to achieve Grutter's benefits. ${ }^{19}$ Part VI concludes.

\section{The Social ANd Legal Definitions AND CRITICISMS OF DIVERSITY}

Those on the front line of the affirmative action battle made a calculated decision to embrace diversity as a way to hold on to opportunities to redress the structural inequality both past and present. ${ }^{20}$ However, those in the social scientific community believed that diversity might possibly offer a more effective solution to addressing current societal ills. ${ }^{21}$

\footnotetext{
${ }^{18}$ See Carbado \& Gulati, supra note 14.

${ }^{19}$ I borrow heavily from Claude Steele here. In his groundbreaking work on Stereotype Threat Theory and the effect it has on minority students based on their individual identities, Steele observes that not only can the effects vary by eliminating the stereotype threat, but also that the identities are adaptable because we have what Steele, a social psychologist, calls social identities. Goffman, a sociologist, would call these identities our contextualized master statuses. Steele calls this contextualization a set of contingencies, "realities down on the ground that the person ha(s) to deal with because they ha[ve] a [particular] identity." Claude Steele, Whistling Vivaldi and Other Clues to How Stereotypes AFFECT Us 83-84 (2010). He calls these identity contingencies. Most insightfully, he states we cannot change identities and their internal manifestations, but we can change contingencies. Id.

${ }^{20}$ At the time the University of Michigan Law School's lawyers were contemplating how best to frame their legal argument, they not only evaluated Patricia Gurin's research on diversity but also examined Claude Steele's extensive body of work on stereotype threat theory. While Steele prepared a report on the challenges with merit-based testing for admission, the legal team chose to use the benefits of diversity for all students model. See Supporting Research for Admissions Lawsuits, UNIV. OF MicH., http://www.vpcomm.umich.edu/ admissions/research/ (last updated Sept. 8, 2009). Relying on challenging the structural model of admissions that benefits Whites (mostly) would have been a tactical failure. The "benefits for all" strategy lined up with Derrick Bell's Interest Convergence Theory. See Derrick A. Bell, Jr., Brown v. Board of Education and the Interest Convergence Dilemma, 93 HARV. L. REV. 518, 523 (1980).

${ }^{21}$ Hurtado wrote that diversity could assist in the "production of citizens for a multicultural society that can result in leadership with greater social awareness and the complex thinking skills to alleviate social problems related to the complexities of inequality." Sylvia Hurtado, Linking Diversity with the Educational and Civic Missions of Higher Education, 30 REV. OF HiGHER EdUC. 185, 193 (2006).
} 


\section{A. Social Scientific Definition of Diversity}

Gottfredson et al., in reflecting on Hurtado's comments that diversity could develop skills in students that would help them address social inequality, ${ }^{22}$ wrote that "if diversifying student bodies across the country creates better citizens in the way Hurtado described, then focusing on academic outcomes for all students may alleviate more social problems than affirmative action intended solely for the purposes of proportional representation. ${ }^{, 23}$ This pragmatic approach appears in much of the social scientific work on diversity. Specifically, social scientists spend less time worrying about the appropriateness of affirmative action from a legal standpoint and more time on how best to make diversity an effective tool in creating social good.

In contemplating how best to achieve the benefits of diversity, Allport identified two important conditions to lower prejudice in diverse groups. The "dominant" or "in-group" must be exposed to the "out-group" 24 in casual situations in which the out-group has equal social status with the dominant group. ${ }^{25}$ In addition, the interactions should occur in a cooperative environment with the support and encouragement of a person in authority. ${ }^{26}$ These suppositions served as the basis for Contact Theory, which became the guiding influence for recent notions of how to define and measure the benefits of diversity.

Specifically, two types of diversity have emerged in the social scientific community as they relate to higher education. The first is known as "contact diversity." 27 Under this construct, researchers measure the frequency and sometimes quality and valence of contact between individuals from different racial, ethnic, gender, religious, or class backgrounds to evaluate outcomes associated

\footnotetext{
${ }^{22} I d$.

${ }^{23}$ Nisha C. Gottfredson et al., Does Diversity at Undergraduate Institutions Influence Student Outcomes?, 1 J. DiVERSITY HighER EdUC. 80 (2008).

24 "Out-group" refers to the group of individuals with which the dominant or in-group does not identify. Instead the in-group compares itself to the out-group and uses the comparisons as a basis for self-esteem and social status in its identification with the in-group. Created as part of Social Identity Theory, out groups frequently suffer from oppression and stereotyping as in-group members tend to exaggerate differences from the out-group as a basis for discrimination. See Henri Tajfel, Social Identity in Intergroup Behavior, 13 SOC. SCI. INFO. 65 (1974).

${ }^{25}$ Interestingly, one of the ways to achieve this equal status is to create a critical mass of students of color. Grutter v. Bollinger, 539 U.S. 306, 318 (2003) (discussing the testimony of Erica Munzel).

${ }^{26}$ See Gordon Allport, The NAture of Prejudice (1954).

${ }^{27}$ Gottfredson et al., supra note 23 .
} 
with these types of contacts. ${ }^{28}$ Some of the benefits measured from contact diversity include reducing prejudice, ${ }^{29}$ increasing positive attitudes towards the outgroup, ${ }^{30}$ and generalizing those attitudes to other out-groups. ${ }^{31}$ Other benefits include the ability to think critically ${ }^{32}$ and with open-mindedness, ${ }^{33}$ participate in civic engagement as a citizen concerned for the public good, ${ }^{34}$ and the willingness to engage in perspective taking ${ }^{35}$ with integrative complexity. ${ }^{36}$

The second type of diversity is defined as "classroom diversity,",37 but for clarity purposes, I will call it "content diversity." In this situation, social scientists observe student exposure to diverse minority and cultural issues in a formal academic setting. Researchers examine more narrowly the benefits for students taking required courses in multicultural issues. The benefits include reduced racist attitudes and stereotypes. ${ }^{38}$ It appears these were just the types of benefits the Grutter Court found as palatable reasons to preserve affirmative action. However, legal conceptions of diversity focus solely on contact diversity. Content diversity seems to be missing from the equation.

${ }^{28}$ See, e.g., Anthony L. Antonio, The Role of Interracial Interaction in the Development of Leadership Skills and Cultural Knowledge and Understanding, 42 RES. IN HIGHER EDUC. 593 (2001); Patricia Gurin et al., Diversity and Higher Education: Theory and Impact on Educational Outcomes, 72 HARV. Educ. Outcomes 330 (2002); Sylvia Hurtado, The Next Generation of Diversity and Intergroup Relation Research, 61 J. Soc. Issues 595 (2005); T.F. Pettigrew \& L. R. Tropp, A Meta-analytic Test of Intergroup Contact Theory, 90 J. Personality \& Soc. Psychol. 751 (2006); Daniel A. Powers \& Christopher G. Ellison, Interracial Contact and Black Racial Attitudes: The Contact Hypothesis and Selectivity Bias, 74 SOC. ForCES 205 (1995).

${ }^{29}$ Pettigrew \& Tropp, supra note 28.

${ }^{30} I d$.

${ }^{31} I d$.

${ }^{32}$ Hurtado, supra note 28.

${ }^{33} I d$.

${ }^{34} I d$.

${ }^{35}$ See Gurin et al., supra note 28.

${ }^{36}$ This concept measures the ability to comprehend and internalize different perspectives into one's own point of view. Antonio, supra note 28.

${ }^{37}$ Gottfredson et al., supra note 23 , at 82 .

${ }^{38}$ Mitchell J. Chang, The Impact of an Undergraduate Diversity Course Requirement on Students' Racial Views and Attitudes, 51 J. OF GEN. EdUC., No. 1, 2002 at 21. 


\section{B. Legal Definitions of Diversity and its Benefits in the Court and Academy}

These were certainly the benefits Justice O'Connor had in mind when she crafted the Grutter opinion. She adopted a careful set of linguistics in describing what diversity is. She used the term as both a noun and an adjective. Diversity appears as a noun when O'Connor wrote, "The law school does not, however, limit in any way, the broad range of qualities and experiences that may be considered valuable contributions to student body diversity." ${ }^{.39}$ This usage indicates that diversity certainly includes race and ethnicity but is not limited to that definition. She used diversity as an adjective to agree that the law school can enroll a critical mass of under-represented minority students to "further its compelling state interest in securing the educational benefits of a diverse student body." is important because an object-a person of a particular race or ethnicity-is interchangeable with a modifier, an educational enhancement for an institution. Minority racial identity becomes the justification for a student's presence on campus; it is seen as a set of experiences and qualities. Race is a salient feature. ${ }^{41}$ In other words, a person with a particular master status ${ }^{42}$ is defined as either beneficial to the institution or not.

While neither O'Connor nor Michigan Law School defines the other types of diversity, one can imagine that prior work experience, particular artistic talent, or even athletic abilities also may be considered diverse contributions. The problem is that no other type of diversity contribution is also a master status. ${ }^{43}$ For O'Connor,

${ }^{39}$ Grutter v. Bollinger, 539 U.S. 306, 338 (2003).

${ }^{40} I d$.

${ }^{41}$ In this sense, Grutter adopts a view of race as an empirical fact. See generally John O. Calmore, Exploring Michael Omi's "Messy" Real World of Race: An Essay for "Naked People Longing to Swim Free," 15 LAW \& INEQ. 25 (1997).

${ }^{42}$ See Erving Goffman, Stigma: Notes on the Management of Spoiled Identity (1963).

${ }^{43}$ Stephanie Wildman, in describing how difficult it is to teach by analogy using a person's master status (my words, not hers), observed that she could not find a meaningful comparison for Anglo students to understand racial oppression. A colleague suggested that she use the example of being wrongfully thought of as being gay or a lesbian. She writes: "Comparing oppressions may lead to a false sense of understanding. The lesson about subordination would come at the expense of implicitly validating oppression on the basis of sexual orientation." Stephanie Wildman, Privilege and Liberalism in Legal Education: Teaching and Learning in a Diverse Environment, 10 BERKELEY WOMEN's L.J. 88, 90 (1995). However, the same danger occurs when comparing one's racial status as a diverse contribution in the same way as non-master status characteristics would be diversity contributions. While all of these characteristics are used to enhance the student body's educational experience, these characteristics will enhance in different ways. Understanding a musician, baseball player, or community health worker's 
race is at once salient for educational advantages but impervious to structural inequalities. ${ }^{44}$ In other words, O'Connor decontextualizes race, framing it as just another interesting attribute a person can bring into the classroom. Yet, the master status of race carries with it a social narrative unlike any other type of "diverse" characteristic.

However, diversity alone does not present the full picture. The University of Michigan Law School carefully laid out its desire to create an unquantifiable concentration of under-represented minorities in each class so that these students could contribute in a meaningful way without feeling isolated. The law school referred to this additional conception of diversity as "critical mass." 45

The Court seemed to understand that in order to achieve the three benefits the law school's expert witnesses articulated, and that O'Connor embraced as "substantial," 46 this particular definition of diversity, one that creates meaningful representation of under-represented minority students, was important. The supposed benefits articulated include the promotion of racial understanding, better preparation of students entering an increasingly diverse workforce and society, and dismantling racial stereotypes. ${ }^{47}$

While diversity, critical mass, and its benefits took center stage in the Grutter case, these terms garnered the legal academy's attention twenty-five years earlier when Justice Powell introduced the diversity idea in Bakke. ${ }^{48}$ The terms returned to

view is very different from understanding what oppression is like for an individual who cannot choose when to reveal his or her educational enhancing characteristic, i.e., her race or ethnicity or gender, and knows no rewards come from possessing these master statuses.

${ }^{44}$ O'Connor wishes to acknowledge that race has some meaning in society in that it shapes how individuals interact with each other in corporations and the military, but she does not want to acknowledge the structural consequences of the long history of racial interactions. See Marvin Jones, What Does Diversity Mean in Legal Education and Beyond? Plessy's Ghost: Grutter, Seattle and the Quiet Reversal of Brown, 35 PEPP. L. REV. 583 (2008). In essence, O'Connor is operating under the fallacy Blauner articulated that race and racial oppression are not independent dynamic forces but are reduced to other causal determinants, such as economics or psychological forces. ROBERT BLAUNER, RACIAL OPPRESSION IN AMERICA 82-104 (1972). Furthermore, her legal analysis is consistent with Sleeter's point that racism is, in fact, blameless. Christine E. Sleeter, White Silence, White Solidarity, in RACE Traitor 257, 259 (Noel Ignatiev \& John Garvey eds., 1996). Thus, Grutter is consistent with the line of analysis that because racism is blameless, affirmative action cannot be employed as a reparations tool.

${ }^{45}$ Grutter v. Bollinger, 539 U.S. 306, 330 (2003) (discussing the testimony of Erica Munzel).

${ }^{46} I d$.

${ }^{47} I d$. at 331 .

${ }^{48}$ Regents of Univ. of Cal. v. Bakke, 438 U.S. 265 (1978). 
prominence more recently as the backlash against affirmative action gained full steam. ${ }^{49}$ However, as Carbado and Gulati observed, a lot of diversity literature exhibits the same deficiencies. It does not define the term "diversity." ${ }^{, P 0}$ Perhaps the omission occurs because, as Carbado and Gulati theorize, Powell did not clearly articulate the term in Bakke. ${ }^{51}$ Regardless, the authors create a useful taxonomy of diversity that situates the definition within its normative function as it relates to higher education. Specifically, they define racial diversity as "a relationship that exists between race and social experiences on the one hand and knowledge and practices on the other. Central to racial diversity is the notion that how we experience, think about, and conduct ourselves in society is shaped, though not determined, by our race. ${ }^{, 52}$ It is precisely this point that higher education has not fully achieved in the current configuration of diversity on a colorblind campus. Nor can it by relying on critical mass.

While Carbado and Gulati's taxonomy includes seven functional categories, I believe the nomenclature can be reduced into two modalities - institutional and individual utilities - for our purposes here. These modalities create a space for a fully engaged citizenry that provides rich content and expansive paradigms of thought. ${ }^{53}$ Furthermore, as the results demonstrate below, institutions of higher learning are minimally capable of creating functional diversity and achieving the Grutter goals. They cannot complete the task relying on critical mass.

The same criticism regarding the clarity of meaning also applies to the term "critical mass." Addis points out that "[w]hile there is a degree of certainty as to what the phrase means in the scientific realm, there does not seem to be such clarity in relation to the application of the phrase in the social and political world. Indeed, the term's clarity has not matched its popularity." ${ }^{~}$ In the legal domain, within

\footnotetext{
${ }^{49}$ The critical mass concept appeared in the courthouse prior to Grutter in three other education cases. See United States v. Virginia, 518 U.S. 515, 523 (1996); Comfort ex rel. Neumyer v. Lynn Sch. Comm., 263 F. Supp. 2d. 209 (D. Mass. 2003), superseded by, 283 F. Supp. 2d 328 (2003); Oliver v. Kalamazoo, 498 F. Supp. 732, 747-48 (W.D. Mich. 1980), vacated, 706 F.2d 757 (6th Cir. 1983).

${ }^{50}$ See Carbado \& Gulati, supra note 14.

${ }^{51} I d$. at 1150 .

${ }^{52}$ Id. at $1153-54$.

${ }^{53}$ The functions are inclusion, social meaning, citizenship, belonging, colorblindness, speech, and institutional culture. Id. at 1154 .

${ }^{54}$ Adeno Addis, The Concept of Critical Mass in Legal Discourse, 29 CARDOzo L. ReV. 97, 99 (2007).
} 
higher education and affirmative action discourse, Addis argues that the term finds use as both an analogy and a metaphor without clear definition. ${ }^{55}$

While the terms may elude a specific meaning, diversity, at least, has not escaped a more specialized taxonomy. Perhaps borrowing from the social-science literature, the law has conjured up three additional types of diversity: structural diversity, which refers to the percent of non-white students at a university; classroom diversity, which examines a student's exposure to knowledge about race and ethnicity in the classroom setting; and informal interactional diversity, which measures the extent to which students interact outside of the classroom with peers of different racial or ethnic backgrounds. ${ }^{56}$

Perhaps because the terms resist clarity, they suffer scathing criticism from both sides of the affirmative action fence. However, much of that criticism is resting on a set of assumptions without empirical support. This paper hopes to start filling in that gap.

\section{Criticisms of the Diversity Model}

Broadly speaking, four main criticisms weigh against diversity. Some proponents of affirmative action view the diversity model as a weak and colorblind betrayal of the original goal of affirmative action: to redress structural racism and open opportunities to minority groups historically and currently not afforded them. ${ }^{57}$ Moreover, proponents worry whether the contemplated advantages of diversity benefit only white students rather than all students. ${ }^{58}$ In addition, both sides question whether empirical research can support these alleged benefits. ${ }^{59}$

${ }^{55} I d$. at 111 . The analogy is drawn to the scientific realm where mass refers to numbers and "critical" refers to "meaningful." As a metaphor, it simply means an idea. Id.

${ }^{56}$ See Dorothy Brown, Taking Grutter Seriously, 43 Hous. L. REV. 1 (2006).

${ }^{57}$ See, e.g., Bell, supra note 1; Colin S. Diver, From Equality to Diversity: The Detour from Brown to Grutter, 2004 U. ILL. L. REV. 691, 694 (2004) (observing that diversity is a weaker argument than remediation in support of affirmative action); Bryan K. Fair, Re(Caste)ing Equality Theory: Will Grutter Survive Itself by 2028?, 7 U. PA. J. CONST. L. 721, 722 (2005); Matthew Scutari, "The Great Equalizer": Making Sense of the Supreme Court's Equal Protection Jurisprudence in American Public Education and Beyond, 97 GEO. L.J. 917 (2009).

${ }^{58}$ See Kenneth B. Nunn, Diversity as a Dead-End, 35 PePp. L. Rev. 705 (2008); Cedric Merlin Powell, Rhetorical Neutrality: Colorblindness, Frederick Douglass, and Inverted Critical Race Theory, 56 CLEV. ST. L. REV. 823 (2008).

59 See Angelo Ancheta, Scientific Evidence and Equal Protection of the Law 6 (2006) ("[M]any judges may lack the technical expertise in science and mathematics that would enable them to become the types of 'amateur scientists' who could be truly effective gatekeepers."); Derrick Darby, Educational Inequality and the Science of Diversity in Grutter: A Lesson for the Reparations Debate in 
Finally, opponents ask whether student diversity offers any educational benefits at all. ${ }^{60}$ Or instead, does it merely disguise a thinly veiled attempt to remediate past racial wrongs using quotas? ${ }^{61}$

\section{Affirmative Action Proponents' Critique of the Diversity Model}

Even prior to Grutter, scholars warned against the employment of diversity as a means of keeping affirmative action alive. ${ }^{62}$ Lawrence warned that the diversity paradigm would protect white privilege rather than redress the structural and institutional barriers of discrimination in higher education. ${ }^{63}$

Bell reaffirmed these warnings and charged that the diversity paradigm amounted to a betrayal of affirmative action's original purpose. ${ }^{64} \mathrm{He}$ observed that the diversity strategy invites more litigation, gives credence to standardized "meritbased" admission profiles that advantage privileged white applicants, and distracts from addressing the root causes of inequality-poverty and discrimination. ${ }^{65}$

Furthermore, advocates expressed their major concern of tokenism, ${ }^{66}$ which creates two main issues: First, students of color learn that resources are delineated based on race and that they must perform according to white normative

the Age of Obama, 57 U. KAN. L. REV. 755, 779-80 (2009) (arguing that relying on empirical findings as the authority for the majority opinion leaves the position open to attack when contrary findings reveal themselves); Brian N. Lizotte, The Diversity Rationale: Unprovable, Uncompelling, 11 MICH. J. RACE \& L. 625 (2006) (providing a scathing critique of the theory, methodologies, and logic of the studies the Court relied on to support the compelling interest of student diversity).

${ }^{60}$ See Grutter v. Bollinger, 539 U.S. 306, 347 (2003) (Scalia, J., concurring in part and dissenting in part) ("This, of course, is not an educational benefit ... [f]or it is a lesson of life rather than lawessentially the same lesson taught to ... people three feet shorter and 20 years younger than the fullgrown adults at the University of Michigan Law School . ...”).

${ }^{61}$ See id. at 374 (Thomas, J., concurring in part and dissenting in part) (observing that Equal Protection Clause demands the elimination of racial barriers, not their creation, to achieve a particular social order).

${ }^{62}$ See Charles Lawrence, Two Views of the River, A Critique of the Liberal Defense of Affirmative Action, 101 Colum. L. REV. 928, 940 (2001).

${ }^{63}$ Id. at 941; see also Richard Delgado, Affirmative Action as a Majoritarian Device: Do You Really Want to Be a Role Model?, 89 MICH. L. REV. 1222, 1224 (1991) (arguing that affirmative action is a homeostat in which institutions admit enough students of color to maintain stabilization without infringing on the privileged group).

${ }^{64}$ Derrick Bell, Diversity's Distractions, 103 CoLuM. L. REV. 1622 (2003).

${ }^{65} I d$.

${ }^{66}$ Nunn, supra note 58 , at $722-23$. 
expectations of race. In other words, these students must "perform their ethnicity for admissions officers. ${ }^{\prime 67}$ Second, the risk of stereotype threat follows from these recitals, as students may soon learn the classroom environment requires more performance. As mere tokens, students of color must confront the stereotype associated with their racial or ethnic background or gender ${ }^{68}$ and consistently demonstrate that they do not fit it. ${ }^{69}$

While minority students can feel the stress of tokenism by being one of too few, affirmative action supporters also argued that minority students could feel the stress of being one of too many. "When the proportion of racial and ethnic minorities increases at a campus, the salience of racial and ethnic difference grows. The resulting sense of balkanization may harm the academic performance of students of color by making them feel isolated ...."70

Critics conveyed a related concern that while universities professed a desire for critical mass, a high risk of tokenism, balkanization, or both could occur because of who controls definitions of diversity on campus (not the students of color). "Meaningful numbers"- the phrase adopted by the University of Michigan Law School as best explaining critical mass - "[is] controlled by the educational institution and is outside the influence of the minority communities within them.",71 Ultimately, the criticisms of the diversity model can be summed up as a way to enhance the curriculum ${ }^{72}$ of white students without sacrificing their elite status. But

${ }^{67}$ Cristina M. Rodriguez, Against Individualized Consideration 5-7 (N.Y.U. Sch. L. Pub. L. \& Legal Theory Res. Paper Series, Working Paper No. 08-18, 2008), available at http://www.ssrn.com/abstract=1148352.

${ }^{68}$ The mere salience of the threat of the stereotype being attached can affect student performance. Rachel Moran, Diversity and its Discontents: The End of Affirmative Action at Boalt Hall, 88 CAL. L. REV. 2241, 2258-59 (2000).

${ }^{69}$ As Claude Steele points out, the stress of having to ensure that the stereotype does not attach can significantly impact student performance. Claude M. Steele, A Threat in the Air: How Stereotypes Shape Intellectual Identity and Performance, 52 AM. PsYCHOLOGIST 613, 614 (1997).

${ }^{70}$ Moran, supra note 68 , at 2264. Balkanization occurs when students withdraw from the larger campus community into factions based on racial or ethnic group status, and each group resists interaction with each other. See id. at 2265.

${ }^{71}$ Nunn, supra note 58 , at 723 .

72 Bowen refers to this rationale of enhancing the curriculum through racial diversity as "curriculum diversity" in which students of color are present in the classroom primarily as an educational tool for white students. Bowen, supra note 13, at 1242. 
students of color bear the burden (a criticism not too far removed from that of Justice Thomas' observations). ${ }^{73}$

\section{Affirmative Action Opponents' Critique of the Diversity Model}

Opponents of affirmative action criticize the diversity model on the same bases as they do affirmative action generally.

First, Justice Thomas warned in his Grutter dissent that universities and law schools employed diversity as a methodological tool to achieve educational benefits but that diversity could not be an end in itself. However, he was skeptical that this approach could accomplish the law school's educational goals. Instead, he chastised the majority for not seeing the diversity model for what it was: nothing more than a classroom aesthetic. ${ }^{74}$ Thomas also asserted that the majority used the end goal of diversity and the methodological approach of diversity interchangeably. ${ }^{75}$

Second, the interchangeability of these terms reveals that a quota system is at play, according to Thomas. ${ }^{76}$ In Grutter, Rehnquist accuses the majority of relying on diversity as a means to educational benefits as merely a ruse to achieve racial

${ }^{73}$ See, e.g., Deborah Jones Merritt, Brown's Legacy: The Promises and Pittfalls of Judicial Relief, 56 NeGro Educ. Rev. 51, 53 (2005) ("Selective colleges have just the 'right' mix of white and minority students, enough African American and Latino students to give the campus an urbane, cosmopolitan air without threatening the white campus majority.").

${ }^{74}$ He wrote,

"[D]iversity," for all of its devotees, is more a fashionable catch-phrase than it is a useful term, especially when something as serious as racial discrimination is at issue. Because the Equal Protection Clause renders the color of one's skin constitutionally irrelevant to the Law School's mission, I refer to the Law School's interest as an "aesthetic." That is, the Law School wants to have a certain appearance, from the shape of the desks and tables in its classrooms to the color of the students sitting at them.

Grutter v. Bollinger, 539 U.S. 306, 367 n.3 (2003) (Thomas, J., concurring in part and dissenting in part).

${ }^{75}$ Id. at 355 .

${ }^{76}$ Id. See also Regents of Univ. of Calif. v. Bakke, 438 U.S. 265, 319 (1978) (explaining that the quota system tells applicants who are not Negro, Asian, or Chicano that they are totally excluded from a specific percentage of the seats in an entering class); Sumi Cho, From Massive Resistance, to Passive Resistance, to Righteous Resistance Understanding the Culture Wars from Brown to Grutter, 7 U. PA. J. CONST. L. 809, 830 (2005). However, we do not frame the legacy admissions program as a quota system that tells applicants who are first generation college applicants that they are totally excluded from a specific percentage of the seats in an entering class. 
PAGE

balancing. ${ }^{77}$ In fact, Scalia agrees and proclaims, "I join the opinion of the Chief Justice. As he demonstrates, the University of Michigan Law School's mystical 'critical mass' justification for its discrimination by race challenges even the most gullible mind. The admissions statistics show it to be a sham to cover a scheme of racially proportionate admissions." 78 Outside of the law, Ward Connerly, the individual behind the many anti-affirmative action referenda passed in California, ${ }^{79}$ Washington, ${ }^{80}$ Michigan, ${ }^{81}$ and Nebraska, ${ }^{82}$ as well as media coverage devoted to this topic, effectively communicated affirmative action as reverse discrimination through the use of quotas. ${ }^{83}$ Because the Supreme Court clearly rejected racial balancing as unconstitutional, and the political and media climate equated affirmative action with reverse discrimination, a reference to quota became code for not only impermissible legal goals but also all socially offensive preconceptions associated with affirmative action. ${ }^{84}$

${ }^{77}$ Grutter, 539 U.S. at 347 (Rehnquist, J., dissenting).

${ }^{78}$ Id. at 347-48. See also Lauren Arms, It's Not All Black and White: Race-Based Admissions Purport to Achieve a Critical Mass of Diversity, but in Reality Merely Mask a Pre-Determined Quota of the Ideal Integrated Society, 49 S. TEX. L. REv. 205 (2007); Joshua Levine, Stigma's Opening: Grutter's Diversity Interest(s) and the New Calculus for Affirmative Action in Higher Education, 94 CAL. L. REV. 457 (2006). But see Alex M. Johnson, Defending the Use of Quotas in Affirmative Action: Attacking Racism in the Nineties, 1992 U. ILL. L. REV. 1043, 1060 (1992) (arguing that quotas are an acceptable and necessary tool for higher education admissions when a pool of qualified candidates is available to achieve a class of students reflective of the demographics in society).

${ }^{79}$ Cal. Proposition 209 (1996).

${ }^{80}$ Wash. Initiative 200 (1998).

${ }^{81}$ Mich. Proposition 2 (2006).

${ }^{82}$ Neb. Initiative 424 (2008).

${ }^{83}$ Beydoun, reflecting on how the Michigan Civil Rights Initiative passed, observed that in focus groups conducted by the Racial Justice Working Group, "[p]articipants enter the discussion of affirmative action with misinformation about the extent of the reach of affirmative action programs. Few offer examples beyond quotas for minorities in college admissions and hiring." Khaled Ali Beydoun, Without the Color of Law: The Losing Race Against Colorblindness in Michigan, 12 MicH. J. RACE \& L. 465, 474 (2007) (quoting Memorandum from Al Quinlan and Liz Gerloff, Greenberg Quinlan Rosner, to Trisha Stein (Feb. 24, 2006) (on file with [Beydoun])); see also Ashley M. Hibbett, The Enigma of the Stigma: A Case Study of the Validity of the Stigma Arguments Made in Opposition to Affirmative Action Programs in Higher Education, 21 HARV. BLACK LETTER L.J. 76 (2005) (describing Law \& Order episodes in which black defendants used a defense relying on the harms of affirmative action to explain their crimes); Janine Jackson, Affirmative Action Coverage Ignores Women-and Discrimination, EXTRA!, Jan./Feb. 1999, available at http://www.fair.org/index.php?page=1442.

${ }^{84}$ See Cho, supra note 76. Specifically, among these offensive preconceptions are that certain groups would get a leg up in admissions to school or employment opportunities and thus deny more deserving 
Third, while opponents argued that "quotas" might harm those who do not benefit from affirmative action, they also expressed equal concern for the harm the policy may likewise cause its beneficiaries. ${ }^{85}$ Of all these arguments, the risk of stigma best captures the collective imagination. ${ }^{86}$ Richard Sander received applause for his empirical study outlining the mismatch of students of color in institutions of higher learning through the use of affirmative action and its consequences. ${ }^{87}$

people these opportunities - people who naturally believed they were entitled to these opportunities based on "merit."

${ }^{85}$ For example, Justice Powell rejected employing affirmative action as a tool for remedying past discrimination when innocent parties would be burdened. Likewise, Justice O'Connor was mindful of the same concern. See Grutter v. Bollinger, 539 U.S. 306, 341 (2003); Regents of Univ. of Cal. v. Bakke, 438 U.S. 265, 310 (1978).

${ }^{86}$ Perhaps because this argument deflects focus from the self-interest of opponents of affirmative action, it is so compelling. Instead, the opponent is recreated as altruistic in his or her concern for the groups long oppressed and "misguided" in their belief that redress can be found in affirmative action.

${ }^{87}$ See Richard H. Sander, A Systemic Analysis of Affirmative Action in American Law Schools, 57 STAN. L. REv. 367 (2004). See, e.g., Metro Broad., Inc. v. FCC, 497 U.S. 547, 637 (1990) (Kennedy, J., dissenting) (noting that affirmative action policies impose stigma on their beneficiaries and foster views that they are less able to compete); Richmond v. J.A. Croson Co., 488 U.S. 469, 516 (1989); Charles Murray, Affirmative Racism, in Debating Affirmative Action: Race, Gender, Ethnicity, and the Policies of Inclusion, in Debating Affirmative Action: Race, Gender, Ethnicity, And the Politics of INCLUSION 207 (Nicolaus Mills ed., 1994); Terry Eastland, The Case Against Affirmative Action, 34 WM. \& MARY L. ReV. 33, 34 (1992); see also Thomas J. Kane, Misconceptions in the Debate Over Affirmative Action in College Admissions, in ChILling Admissions: The AfFIRMATIVE ACTION CRisis AND THE SEARCh FOR Alternatives 18 (Gary Orfield \& Edward Miller eds., 1998) ("[T]he most damning charge against affirmative action is that it does more harm than good for the intended beneficiaries, by enticing students to attend colleges where they are unprepared for the competition."); andré douglas pond cummings, Open Water: Affirmative Action, Mismatch Theory and Swarming Predators: A Response to Richard Sander, 44 BRANDEIS L.J. 795, 844 (2006); R.A. Lenhart, Understanding the Mark: Race, Stigma, and Equality in Context, 79 N.Y.U. L. REV. 803, 809-10 (2004) (describing all the ways in which stigma does harm). But see Ian Ayres \& Richard Brooks, Does Affirmative Action Reduce the Number of Black Lawyers?, 57 STAN. L. ReV. 1807 (2004); David L. Chambers et al., The Real Impact of Eliminating Affirmative Action in American Law Schools: An Empirical Critique of Richard Sander's Study, 57 StAN. L. REV. 1855, 1857 (2005) (concluding that eliminating racial preferences would yield a "substantial net decline in the number of African Americans entering the bar"); Cheryl I. Harris \& William C. Kidder, The Black Student Mismatch Myth in Legal Education: The Systemic Flaws in Richard Sander's Affirmative Action Study, 46 J. BlaCKs HigHER EDUC. 102 (2004) (discussing the results of Sander's data and, after their own analysis, drawing the opposite conclusion); Daniel E. Ho, Why Affirmative Action Does Not Cause Black Students to Fail the Bar, 114 Yale L.J. 1997 (2005); Jesse Rothstein \& Albert Yoon, Affirmative Action in Law School Admissions: What Do Racial Preferences Do?, 75 U. CHI. L. REV. 649, 650 (2008) (empirically analyzing Sander's data and concluding that eliminating affirmative action would reduce the number of black lawyers at far greater rates than the increase in the number of black students who might pass the bar exam with the elimination of negligible mismatch effects concentrated in the small pool of the weakest students). 
PAGE

Stigma results when schools admit students of color who are not qualified to attend, so the story goes ${ }^{88}$ - a story oft repeated by Justice Thomas. ${ }^{89}$ In his Grutter dissent, Thomas wrote bitterly that " $[\mathrm{t}]$ hese programs stamp minorities with a badge of inferiority." 90

Thomas also raised the final argument against affirmative action. He warned that such programs would create dependence and a sense of entitlement for their beneficiaries. ${ }^{91}$ However, others pioneered the argument prior to Thomas's dissent in Grutter. Relying on data collected in other countries that applied affirmative action policies, Sowell concluded, among other things, that beneficiaries lacked incentive to perform at their best. ${ }^{92}$ Bloom expounds further and predicts in his analysis of Grutter, "It may cement racial preferences into the social structure as a fundamental entitlement immune from removal regardless of any change in circumstances." 93

While the debate between the benefits and risks associated with affirmative action has played on for decades, the Supreme Court revisited the topic in Grutter, giving deference to empirical data in the search for answers to these competing assertions. $^{94}$ The use of empirical data came with its own costs. A number of legal commentators raised concerns about the reliance on social scientific data, ${ }^{95}$ but one such critique deserves special attention. ${ }^{96}$

\footnotetext{
${ }^{88}$ See John E. Morrison, Colorblindness, Individuality and Merit: An Analysis of the Rhetoric Against Affirmative Action, 79 IowA L. REv. 313, 340-44 (1994) (excellently dissecting how the stigma argument is employed); see also Bowen, supra note 13 (finding stigma argument to be invalid as greater stigma appears to be associated with anti-affirmative action states).

${ }^{89}$ See also Note, Lasting Stigma: Affirmative Action and Clarence Thomas's Prisoners' Rights Jurisprudence, 112 HARV. L. REV. 1331, 1334-36 (1999); andré douglas pond cummings, Grutter v. Bollinger, Clarence Thomas, Affirmative Action and the Treachery of Originalism: "The Sun Don't Shine Here in this Part of Town,” 21 HaRV. BlaCk LetTer L.J. 1, 2 n.5, 6 n.19 (2005).

${ }^{90}$ Grutter v. Bollinger, 539 U.S. 306, 373 (2003).

${ }^{91} I d$.

92 See Thomas Sowell, Affirmative Action Around the World: An Empirical Study (2004). However, Sowell was later critiqued for data selection choices that yielded a desired outcome. $C f$. Harris \& Kidder, supra note 87 (applying the same critique to Richard Sander's empirical conclusions).

${ }^{93}$ Lackland H. Bloom, Jr., Grutter and Gratz: A Critical Analysis, 41 Hous. L. Rev. 459, 512-13 (2004.) However, no one expressed equal concern that lesser performing legacy admit-ted students might become dependent and feel entitled to their admission program.

${ }^{94}$ See Grutter, 539 U.S. at 306.

${ }^{95}$ See, e.g., Darby, supra note 59; Roslyn Arlin Mickelson, Twenty-First Century Social Science on School Racial Diversity and Educational Outcomes, 69 OHIO ST. L.J. 1173, 1175-78 (2008). See also
} 


\title{
D. The Social Science of Diversity and its Limitations
}

Gurin's expert-opinion report played a central role in the argument the University of Michigan Law School put forth to argue the state's compelling interest in affirmative action. ${ }^{97}$ However, Gurin's study, as well as other studies on the benefits of diversity, had limitations in its applicability. Lizotte discusses Gurin's study, as well as others, in detail. ${ }^{98}$

Gurin operationalized the concept of "diversity" in a different way than the Court contemplated it in its rationale. Gurin relied on structural diversity, which can only measure the percentage of students of color on a college campus. Lizotte argues that structural diversity might provide some insight into the potential for the kinds of benefits Gurin discusses, but it cannot be correlated with benefits that most often emerge through classroom contact. Indeed, even Gurin warns that structural diversity is not enough. ${ }^{99}$

Lizotte observed that conversely, those studies measuring the benefits of diversity by counting those students enrolled in ethnic studies courses serve as too narrow a measure of the association between diversity and its benefits at the campus level. In other words, benefits that accumulate for students enrolled in courses designed to address issues related to diversity are not generalizable to the population of students at large. ${ }^{100}$ As Lizotte pointed out, it is difficult to measure

Moran, supra note 68 (summarizing the contrasting studies of the benefits and risks associated with a diverse campus climate).

${ }^{96}$ See Lizotte, supra note 59.

${ }^{97}$ See Expert Witness Report of Patricia Gurin, Gratz v. Bollinger, 122 F. Supp. 2d 811, 822-24 (E.D. Mich. 2000) (No. 97-75321); Expert Witness Report of Patricia Gurin, supra note 10, at 363-426.

${ }^{98}$ Gurin's study found that diversity can create both "learning" and "democracy" outcomes in which students in the most diverse classrooms were more likely to engage in perspective-taking rather than stereotyped thinking and were engaged citizens interacting with diverse others. Expert Witness Report of Patricia Gurin, supra note 10, at 365-66.

99

\begin{abstract}
Although structural diversity increases the probability that students will encounter others of diverse backgrounds, given the U.S. history of race relations, simply attending an ethnically diverse college does not guarantee that students will have the meaningful inter-group interactions that ... are important for the reduction of racial prejudice.
\end{abstract}

Peter Schmidt, "Intergroup Dialogue" Promoted as Using Racial Tension to Teach, CHRON. HigHER EDUC., July 16, 2008, available at $\mathrm{http}$ ://chronicle.com/ article/Intergroup-Dialogue-Promoted/985.

${ }^{100}$ Lizotte, supra note 59, at 648-49. 
whether racial diversity on campus or in just certain types of classes is a good measure of the type of diversity Grutter sought campus wide. ${ }^{101}$

One additional study adds insight to Gurin's important work. A recently published study of data collected in 2004 provides a nuanced look at what differently operationalized types of diversity can offer. ${ }^{102}$

Gottfredson et al. conducted two studies using national samples of undergraduates and law students and found the following results regarding diversity and its attendant benefits: First, content diversity ${ }^{103}$ yielded moderate effects on students' ability to engage new perspectives before forming their own opinions. Similarly, contact diversity ${ }^{104}$ provided small effects. ${ }^{105}$ Significantly, though, only content diversity seemed to increase students' cultural awareness and ability to recognize instances of social inequality. ${ }^{106}$

These results are important because, as discussed in the previous section, skeptics have often warned that diversity would result in nothing more than window dressing. These studies suggest that the benefits the Grutter Court envisioned result when students are engaged in conversations about race in a constructive manner within a racially diverse classroom. However, an important caveat is that the researchers collected this data prior to the reconfigured definitions of affirmative action under Grutter.

As discussed, criticisms and predictions abound on both sides of the affirmative action debate. However, up until now, these criticisms and predictions lacked empirical backing. This study offers the first exploration of the post-Grutter cohorts' perceptions of diversity and its supposed benefits in all types of

${ }^{101} I d$.

${ }^{102}$ See Gottfredson et al., supra note 23.

${ }^{103}$ Recall that content or classroom diversity refers to student engagement with diversity topics as part of the curriculum of the course. Id. at 82 .

${ }^{104}$ Contact diversity refers to the ability of students to interact and engage with students from different racial and ethnic groups than the one to which they belong. Id.

${ }^{105}$ However, it should be noted that classroom diversity and contact diversity are moderately correlated, which means that students in diverse classrooms may also receive increased opportunities to engage with students different than themselves outside of the classroom. Id. at 91.

${ }^{106}$ Id. But see Thomas J. Espenshade \& AleXandria Walton RadFord, No Longer Separate, Not Yet Equal: Race and Class in Elite College AdMission and Campus Life (2009) (finding that students reported the most gains in racial understanding from informal activities like socializing, rather than formal activities like diversity training). 
classrooms on campus. By examining under-represented minority students majoring in the sciences, we can evaluate more broadly how diversity benefits present themselves in classes that may not include a curriculum on issues of race. And in doing so, we can empirically investigate whether any of the criticisms and predictions of a diversity model of affirmative action have come to pass.

\section{METHODS}

The data analyzed in this study originated from a survey ${ }^{107}$ distributed at the Annual Biomedical Research Conference for Minority Students ${ }^{108}$ held in Phoenix, Arizona from November 4-9, 2009. ${ }^{109}$ I selected this particular venue because it provided access to 1,462 undergraduate students and 293 graduate students, ${ }^{110}$ all of whom are under-represented minorities in their respective fields of scientific study. ${ }^{111}$

${ }^{107}$ The survey is attached in Appendix A.

108 The Annual Biomedical Research Conference for Minority Students (ABRCMS) is the largest professional conference for minority biomedical students. It is designed to encourage under-represented minority students to pursue advanced training in the biomedical and behavioral sciences. It also provides resources for these students' mentors. Students compete in poster sessions, meet with graduate school representatives, scientific agencies regarding summer internships, and learn how to be socialized into the academy. The conference attracts 3,300 individuals, including 1,700 undergraduate students, 400 graduate students, 30 postdoctoral scientists, and 1,200 faculty and administrators. Students come from over 350 U.S. colleges and universities. See General Information, ANN. Biomedical ReS. CONF. For MiNORITY STUDENTS, http://www.abrcms.org/page01a.html (last visited Apr. 4, 2012). Thus, students who tend to be highly motivated and have mentors to encourage them to pursue graduate school are more likely to attend this conference.

${ }^{109}$ I gained access to the conference through the approval and support of Clifton Poodry (Director of the Division of Minority Opportunities in Research, National Institute of General Medical Sciences, National Institutes of Health) and Dr. Cliff Houston from the University of Texas.

${ }^{110}$ The conference website posts the specific number of registrants for each year's conference. See General Information, supra note 108.

${ }^{111}$ I chose to collect data on under-represented minority students in the hard sciences because although these students may well take elective courses in ethnic studies, they most likely do not converse in their classes about race and ethnicity issues. You will recall that one of the criticisms of other work on diversity is that the sample involves students in ethnic studies courses, which are too narrow to generalize or base results on campus-wide diversity, which lacks the necessary connection to what occurs in the classroom. Thus, understanding how students of color benefit from diversity in a wide variety of courses outside of the ethnic studies curriculum offers a more meaningful way to examine its effect. Furthermore, while a significant amount of work has been done writing about minority students in undergraduate education generally, see Corinne E. Anderson, A Current Perspective: The Erosion of Affirmative Action in University Admissions, 32 AKRON L. REV. 181 (1999); Margalynne J. Armstrong \& Stephanie M. Wildman, Teaching Race/Teaching Whiteness: Transforming Colorblindness to Color Insight, 86 N.C. L. REV. 635 (2007-2008); Michael J. Kaufman, (Still) Constitutional School 
I collected the survey data from noon until 4 p.m. on the first day of registration. ${ }^{112}$ My research assistant and I approached students after they checked in at the conference's registration center. I asked if they would like to participate in the study, briefly described its goals, and, if they consented, ${ }^{113}$ I asked them to read about the goals and confidentiality assurances before they filled out the survey. In the end, 372 students completed the survey. ${ }^{114}$ The goal of the survey was to have students identify whether the two key benefits the Grutter Court imagined-

Desegregation Strategies: Teaching Racial Literacy to Secondary School Students and Preferencing Racially-Literate Applicants to Higher Education, 13 MICH. J. RACE \& L. 147 (2008); Angela Onwuachi-Willig, The Admission of Legacy Blacks, 60 VAND. L. REV. 1141 (2007); Alfreda A. Sellers Diamond, Serving the Educational Interests of African-American Students at Brown Plus Fifty: The Historically Black College or University and Affirmative Action Programs, 78 TUL. L. REV. 1877 (2004), and in legal education and affirmative action, see Alma Clayton-Pedersen \& Sonja ClaytonPedersen, "Making Excellence Inclusive" in Education and Beyond, 35 PEPP. L. REV. 611 (2007-2008); Jones, supra note 44; Nunn, supra note 58; Adrien Katherine Wing, Race-Based Affirmative Action in American Legal Education, 51 J. LEGAL EdUC. 443 (2001), very little has been written regarding diversity for students in the hard sciences, see Barbara A. Noah, A Prescription for Racial Equality in Medicine, 40 ConN. L. Rev. 675 (2007-2008); Susan Welch \& John Gruhl, Does Bakke Matter? Affirmative Action and Minority Enrollments in Medical and Law Schools, 59 OHIO ST. L.J. 697 (1998). Disparate life expectancies and access to health care remains dramatic between Whites and minority groups. Having minority students in medical school and as doctors, researchers, and health care professionals will have a life-altering impact on these populations. Yet under-represented minorities' under-enrollment in the hard sciences in colleges, graduate schools, and professional schools is more significant than in any other fields of study. Understanding how diversity does or does not benefit these particular students becomes crucial. See generally Women, Minorities, and Persons with Disabilities in Science and Engineering, NAT’L SCI. FOUND. (Feb. 2011), http://www.nsf.gov/ statistics/wmpd/.

${ }^{112}$ Per the terms of the ABCRMS.org agreement, in order to conduct the study I had to complete data collection before the actual conference events began at 4:30 p.m.

${ }^{113}$ This study was approved by the Human Subjects Review Board. I was given a certificate of exemption. It is on file with the author.

${ }^{114}$ It is important to note that this is not a random sample. Furthermore, it is impossible to calculate a true response rate, as not all students had access to the survey. I can say, however, that of the 400 students whom we did approach, only 28 declined to participate - thus $93 \%$ of the students chose to respond to the survey. I cannot say with confidence that no bias exists in the sample. Of those that chose not to participate, most stated that they were under time constraints. As stated earlier, the sample size is adequate as an exploratory study but cannot be generalized to the population at large.

Furthermore, readers may have additional questions about the demographics of general population of conference attendees or the type of schools the respondents attended. The ABCRMS does not keep this level of data. In addition, the Human Subjects Review Board limited the type of questions I could ask on the survey. For example, I could not ask the name of the school the respondent attended. Without a doubt, these results demand that additional research be conducted. What we can say about the sample is that these are high-achieving students being mentored to continue their academic careers in public and private historically black colleges and universities (HBCUs) and traditionally white schools in twenty states, two territories, and Mexico. 
increased racial understanding and destruction of stereotypes - had come to fruition in a diverse classroom.

I separated the survey into three sections because I sought to distinguish three themes within the study. In the first section, I attempted to identify how students conceived of diversity in their own words, prior to seeing the rest of the survey questions. In addition, I asked what benefits they imagined could result from diversity, and finally, the nature of their experiences (if any) in a diverse classroom environment. The next section was devoted to gathering demographic data about the respondents. These data included questions on gender, race, year in school, class (as measured by parents' educational attainment), and the type and location of school they attended.

The last section asked students to describe their typical classroom population based on race and gender diversity and their ideal classroom population based on race and gender diversity. In addition, I asked students to rate twenty statements on a scale of one to six, with a rating of one meaning "strongly disagree" and a rating of six meaning "strongly agree." Ten of the statements asked students to contemplate the benefits of being in a classroom with students of a different racial or ethnic background than their own to simply measure a diverse classroom. The next ten statements asked students to contemplate the benefits of being in a classroom with students of the same racial or ethnic background as their own in order to measure critical mass. ${ }^{115}$

I chose to gather data on the structural diversity within a classroom, as opposed to on the campus at large, because classroom diversity offers a more accurate measure of the benefits a student might encounter. In doing so, I hope to identify possible clear connections between a diverse classroom and the Grutter objectives. Furthermore, by focusing on students not majoring in subject areas that specifically deal with race and ethnicity issues, I can better examine the impact of diversity across courses that typically do not address these issues. ${ }^{116}$ Thus, these

\footnotetext{
115 These statements drew on the benefits articulated in Gurin's work, the expert witness for the law school in Grutter, and the arguments that the law school and others have articulated regarding the benefits of diversity. The complete survey is in Appendix A. Diversity is defined simply as being in a classroom with people who are of a different racial or ethnic background than the respondent. The critical mass measure is defined simply as being in a classroom with more than one other individual who is of the same racial or ethnic background as the respondent.

${ }^{116}$ But see ESPENSHADE \& RADFORD, supra note 106 (finding that forty percent of students at the ten most selective institutions in the country attending school between 1980 and the late 1990s took at least one ethnic studies class).
} 
U N I V E R S I T Y O F P I T T S B U R G H L A W R E V I E W

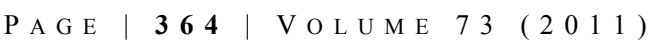

methodological strategies are designed to address specifically the benefits associated with contact diversity. ${ }^{117}$

I operationalized the benefits of diversity by categorizing the statements into three groups: the benefits associated with cognitive successes, the benefits associated with increased racial understanding, and the removal or decrease of stigma. The first two categories are designed to answer the question of whether students of color increase their racial understanding by being in a diverse classroom, a critical mass classroom, or both. The last category is designed to answer the question of whether diversity functions to achieve the second Grutter goal of dismantling the effects of racial stereotyping by being in a diverse or critical mass classroom.

In addition, I also drafted statements to ask students to reflect not only on their own experiences but also on those of others in class. Finally, I attempted to mitigate the effects of response bias in a number of ways. First, students filled out the survey in a space of their choosing away from others, thus avoiding the subconscious influence of nearby peers in a classroom setting. Students sat anywhere they chose in an anonymous lobby. I further reduced response bias by allowing students to simply drop completed surveys in a box, rather than hand them back to me or my research assistant. In addition, I asked students if they valued diversity. This variable acted as a control to determine whether students who valued diversity answered other questions differently from those who viewed diversity as less important.

I coded and analyzed all data using the Statistical Program for the Social Sciences to examine relationships between variables.

\section{Results}

The results of the analysis follow. Recall that the goals of this study were to determine whether the current post-Grutter configuration of affirmative action creates the benefits of cross-racial understanding and the elimination of racial stereotyping and its stigmatic effects for students of color.

The first table indicates the demographics of the sample. Females comprise the majority of the sample. African Americans and Latina/os also dominate the

\footnotetext{
${ }^{117}$ Recall that Gottfredson et al. found that content, not contact diversity, appeared more effective in achieving racial understanding and taking on cognitively other people's points of view. However, content diversity is not a regular part of a student's daily curriculum. Gottfredson et al., supra note 23, at 93.
} 
sample. Similarly, juniors and seniors represent two-thirds of the group. Most of the sample attended state schools. In fact, all students who attended school in an anti-affirmative action state attended a public institution, and nearly $40 \%$ of the students attended historically black colleges and universities. Parents of slightly more than half of the students obtained at least a college degree. Finally, threequarters of the students attended school in affirmative action states.

\section{A. The Benefits of Affirmative Action in a Diverse Classroom}

The next table reveals the benefits students of color perceive from being in a diverse classroom but not necessarily one that achieves critical mass. In this sense, students were asked to reflect on interacting with people from other racial or ethnic groups than their own. The table provides data for the whole sample, as well as for individual racial or ethnic groups. Although variables measure different types of benefits, the results appear in descending order based on the percentage of students in the entire sample agreeing or strongly agreeing with a particular statement.

According to Grutter, minority students interacting in a classroom with individuals of different racial and ethnic membership will increase racial understanding. The results prove true for the most part. Further, under Grutter, one would expect that students of color in a diverse class would find less racial stereotyping and decreased stigma. Unfortunately, the results reveal less than half of the students agree with this supposition. 
U N I V E R S I T Y O F P I T T S B U R G H L A W R E V I E W

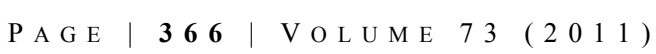

Table 1: Demographics

Gender

Male

Female

Race/Ethnic Group

African American

Latina/o Hispanic

Two or more races

Asian/Pacific Islander

Middle Eastern

Native American

East Indian

West Indian

African

Age

Mean

Year in School

Freshman

Sophomore

Junior

Senior

Graduate

Type of School

Private

Public

Attend HBC/U

Yes

No

Parent Education as a Measure of Class

Less than four-year degree

College or graduate degree
$36.6 \% \quad(135)$

$63.1 \quad(233)$

$51.8 \quad(190)$

$28.6 \quad(105)$

$10.9 \quad(40)$

$5.2 \quad(19)$

$.5 \quad(2)$

$.3 \quad(1)$

$.3 \quad(1)$

$.3 \quad(1)$

$.3 \quad(1)$

22 yrs. 22 yrs.

$5.2 \quad(19)$

$12.6 \quad$ (46)

$29.5 \quad(108)$

$35.8 \quad$ (131)

$14.2 \quad(52)$

$26.8 \quad(99)$

$73.2 \quad(271)$

$38.0 \quad(140)$

$62.0 \quad(228)$

$46.9 \quad(172)$

$53.1 \quad(195)$

Attend School in Affirmative Action State

Affirmative action state $\quad 77.7 \quad$ (286)

Anti-affirmative action state

$22.3 \quad(82)$ 


\section{The Entire Sample ${ }^{118}$}

First, let us examine the importance of racial diversity to the student of color. Indeed, slightly over half $(56 \%)$ agreed or strongly agreed that it was important. ${ }^{119}$ The next series of variables were designed to measure the benefits associated with racial understanding. Notably, the data revealed that most respondents (78\%) agreed or strongly agreed that classroom diversity led them to a greater understanding of others' viewpoints. Thus, racial diversity may lend itself to exposure and understanding of diverse viewpoints.

Further, more than two-thirds of the students believed that diversity in the classroom led to positive interracial experiences. Finally, slightly more than half (57\%) believed that in-class diversity could lead to positive contact diversity. ${ }^{120}$ All the other benefits, however, captured less than half of the students' affirmation.

Slightly less than half of the students felt that diversity in the classroom increased their learning in class $(46 \%)$ or increased their motivation $(44 \%)$. Furthermore, when asked specifically about diversity increasing the ability of white students to engage in perspective taking, ${ }^{121}$ less than $40 \%$ of the students agreed.

The next set of variables examines the benefits associated with eliminating racial stereotyping and reducing stigma through a diverse classroom. Specifically, I explore how this second Grutter goal operates by analyzing racial climate, and internal and external stigma. Overall, just under half (47\%) of the respondents felt that classroom diversity led them to feel more welcome on campus. Similarly, I examined whether a diverse student classroom might improve interactions with professors. ${ }^{122}$

\footnotetext{
${ }^{118}$ The table reveals that students of varying racial and ethnic backgrounds respond differently to the benefits of diversity. While the sample size is too small to show statistically significant differences, these differences will be discussed in Part V.

${ }^{119}$ The variable whether "diversity is important to student" is the strongest and only significant predictor of all other diversity benefits reported. The significance of the "diversity is important to student" variable will be explored in Part V.

${ }^{120}$ Contact diversity refers to the ability of students to have quality and plentiful connections with students from other racial backgrounds.

${ }^{121}$ Recall that perspective taking, as described by Gottfredson et al., is the ability of a student to take on other perspectives before reaching conclusions about the complexities of a new situation. See Gottfredson et al., supra note 23 , at 82 . In other words, increasing cognitive openness allows students to engage in new points of view.

${ }^{122}$ Currently, a significant percentage of science professors in the United States are foreign born and do not have a sophisticated understanding of the nature of race relations in this country. For example, in
} 
U N I V E R S I T Y O F P I T T S B U R G H L A W R E V I E W

PAGE

Table 2: Percent Responding Agree or Strongly Agree to Benefits in a Diverse Classroom by Race/Ethnic Group

\begin{tabular}{|l|c|c|c|c|c|}
\hline & All & $\begin{array}{l}\text { Afr. } \\
\text { Am. }\end{array}$ & Latino/a & $\begin{array}{l}\text { Asian } \\
\text { Am. }\end{array}$ & Multiracial \\
\hline Led to greater understanding & $77.7 \%$ & $76.7 \%$ & $78.7 \%$ & $77.1 \%$ & $84.7 \%$ \\
\hline $\begin{array}{l}\text { Promoted positive interracial experiences for } \\
\text { student in and out of class }\end{array}$ & 68.3 & 62.3 & 69.7 & 63.2 & 74.4 \\
\hline Importance to student & 56.5 & 54.6 & 53.1 & 52.7 & 65.0 \\
\hline $\begin{array}{l}\text { Led to positive interracial experiences for } \\
\text { other students }\end{array}$ & 56.4 & 46.4 & 63.6 & 68.4 & 63.2 \\
\hline Felt more welcome on campus & 46.7 & 41.3 & 53.0 & 63.1 & 41.0 \\
\hline Student learns more in classes & 46.0 & 43.2 & 50.0 & 42.1 & 42.5 \\
\hline Student became more motivated & 44.0 & 43.2 & 45.5 & 47.4 & 38.4 \\
\hline Decreased overt racism & 43.4 & 35.1 & 53.1 & 47.4 & 51.3 \\
\hline Led to white students' perspective taking & 39.3 & 28.5 & 44.6 & 42.2 & 55.2 \\
\hline $\begin{array}{l}\text { Led to more positive interactions with } \\
\text { professor }\end{array}$ & 39.1 & 37.5 & 38.5 & 26.3 & 47.5 \\
\hline Decreased rate of qualifications questioned & 33.6 & 30.1 & 40.6 & 26.3 & 42.5 \\
\hline $\begin{array}{l}\text { Decreased students' pressure to prove } \\
\text { themselves because of race/ethnicity }\end{array}$ & 31.1 & 29.1 & 39.1 & 33.3 & 45.0 \\
\hline
\end{tabular}

Less than $40 \%$ agreed that diverse students in the class led to more positive interactions with professors. Moreover, only $43 \%$ felt that diversity in the classroom decreased overt racism. ${ }^{123}$

Similarly perplexing results arose from the stigma variables, where one would anticipate decreased racial stereotyping under Grutter. For the external stigma variable - the extent to which students feel stigmatized by others - only about onethird of the students agreed or strongly agreed that a diverse classroom decreased

$2008,33 \%$ of faculty in computer sciences, $26 \%$ in engineering, $33 \%$ in math, and $22 \%$ in physical sciences were from other countries. Christine M. Matthews, Cong. Research Serv., Foreign SCIENCE AND ENGINEERING PRESENCE IN U.S. INSTITUTIONS AND the LABOR FORCE 2 n.6 (2008); see also Julie J. Park \& Nida Denson, Attitudes and Advocacy: Understanding Faculty Views on Racial/Ethnic Diversity, 80 J. Higher EdUC. 415, 422, 429 (2009) (asserting that faculty in engineering were least likely to score high on the diversity advocacy measure and faculty in math and sciences were most likely to fall low on the diversity advocacy scale).

${ }^{123}$ Students were free to define overt racism as they saw fit. I did not provide examples or define it for them in the survey. 
the rate at which others questioned their qualifications. Furthermore, less than a third of students believed that diverse environments decreased internal stigma-the extent to which students internalize doubts surrounding their ability or right to attend school. Specifically, I asked whether diversity decreased the pressure students felt to prove themselves based on race or ethnicity. ${ }^{124}$

\section{Diversity Benefits in Affirmative Action vs. Anti- Affirmative Action States}

Table Three shows the same results regarding the benefits of diversity but compares responses based on whether a student attended school in an affirmative action or anti-affirmative action state. ${ }^{125}$ Under the logic of Grutter, affirmative action states would produce more students experiencing the benefits of diversity. The numbers reveal some surprising results.

Again, in order to determine whether bias is present in a student response, I examined whether a relationship exists between the students' schools' affirmative action policy and whether they view classroom diversity as important. In fact, regardless of where students attended, the same distribution occurs between students who are ambivalent, disagree, or strongly disagree on the importance of a diverse classroom. In other words, whether one attends school in an antiaffirmative action state or an affirmative action state does not correlate with whether a student views diversity as important and, therefore, is unlikely to influence how they responded to the questions.

\footnotetext{
${ }^{124}$ I chose to measure stigma using these two variables, as they proved to be salient and statistically significant in my prior work examining stigma. Specifically, these variables operationalize the typical effects of racial stereotypes in an educational setting. Bowen, supra note 13, at 1217.

${ }^{125}$ While ordinarily it would make sense to examine not only whether students attended school in an affirmative action state but also whether they attended a public or private school in an anti-affirmative action state, our sample of students attending schools in anti-affirmative action states exclusively attended public institutions.
} 
U N I V E R S I T Y O F P I T T S B U R G H L A W R E V I E W

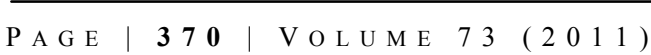

Table 3: Variables for Being in a Diverse Classroom by Affirmative Action

States or Not

\begin{tabular}{|c|c|c|}
\hline & $\begin{array}{c}\text { Anti-Affirmative Action } \\
\text { State }\end{array}$ & Affirmative Action State \\
\hline Led to greater understanding & $77.6 \%$ & $77.7 \%$ \\
\hline $\begin{array}{l}\text { Promoted positive interracial } \\
\text { experiences for student in } \\
\text { and out of class }\end{array}$ & 60.7 & 71.5 \\
\hline Important to student & 56.8 & 57.6 \\
\hline $\begin{array}{l}\text { Led to positive interracial } \\
\text { experiences for other } \\
\text { students inside of class }\end{array}$ & 52.7 & 54.3 \\
\hline $\begin{array}{l}\text { Felt more welcome on } \\
\text { campus }\end{array}$ & 52.5 & 57.2 \\
\hline $\begin{array}{l}\text { Student learns more in } \\
\text { classes }\end{array}$ & 49.4 & 51.5 \\
\hline $\begin{array}{l}\text { Student became more } \\
\text { motivated }\end{array}$ & 41.8 & 44.7 \\
\hline Decreased overt racism & 48.1 & 44.7 \\
\hline $\begin{array}{l}\text { Led to white students' } \\
\text { perspective taking }\end{array}$ & 34.6 & 38.6 \\
\hline $\begin{array}{l}\text { Led to more positive } \\
\text { interactions with professor }\end{array}$ & 38.4 & 41.8 \\
\hline $\begin{array}{l}\text { Decreased rate of } \\
\text { qualifications questioned }\end{array}$ & 36.3 & 32.3 \\
\hline $\begin{array}{l}\text { Decreased students' pressure } \\
\text { to prove themselves because } \\
\text { of race or ethnicity }\end{array}$ & 30.5 & 32.1 \\
\hline
\end{tabular}

While small differences do mark the two groups, none of these differences denote any statistical consequence. This lack of statistical significance suggests that no relationship exists between whether students attend schools with affirmative action and whether the Grutter benefits emerge from learning in a diverse classroom. Recall that diversity, in this instance, refers to students from other racial or ethnic groups than the respondent. Thus, affirmative action does not appear to be associated with whether students of color accrue Grutter benefits when interacting with individuals of different races in the classroom. 
The results might seem counterintuitive. In fact, they are not surprising. As students of color are consistently in the minority in the college classroom regardless of where they attend school, they are always in a position to encounter diversity and its potential benefits. ${ }^{126}$

Thus far, I have reported the results that answer the first question of whether students of color obtain the Grutter benefits of increased racial understanding and reduced racial stereotyping by interacting with individuals from different racial backgrounds than their own. The results examined responses for the whole sample and by comparing students who attended affirmative action institutions with those who did not.

Recall, though, that the Grutter Court found the University of Michigan Law School's goal of creating a classroom mixed with students of varying racial and ethnic backgrounds laudable. ${ }^{127}$ But the law school argued that affirmative action fashioned not just diversity, but also critical mass. ${ }^{128}$ Moreover, the law school asserted that critical mass required representation of students of the same racial or ethnic background. ${ }^{129}$ Critical mass benefits accrue, Michigan believed, more directly to students of color. ${ }^{130}$ Specifically, critical mass seems to be a necessary, but not sufficient, corollary to achieving the second Grutter goal of breaking down racial stereotypes. The University of Michigan Law School argued that only with a sufficient number of students of a particular race in the classroom would students from that background feel comfortable contributing in the classroom without fear of being stereotyped. Nonminority students would learn that no minority viewpoint existed, but rather a myriad of minority student viewpoints could be expressed. ${ }^{131}$ Under these conditions, students could increase their racial understanding. The next section investigates this second vital question.

\footnotetext{
${ }^{126}$ HBCUs may offer the one exception in which minorities make up the majority of students. Emma L. Carew, Diversity Increases at Public Historically Black Colleges, Chron. Higher Educ., Sept. 15, 2009, available at http://chronicle.com/article/Diversity-Increases-at-Public/48410.

${ }^{127}$ See Grutter v. Bollinger, 539 U.S. 306, 330 (2003).

${ }^{128} \mathrm{Id}$. at 316.

${ }^{129}$ Grutter v. Bollinger, 137 F. Supp. 2d 821, 832, 834 (E.D. Mich. 2001), rev'd, 288 F.3d 732 (6th Cir. 2002), aff'd, 539 U.S. 306 (2003).

${ }^{130}$ Addis, supra note 54, at 123.

${ }^{131}$ Grutter v. Bollinger, 539 U.S. 306, 319-20 (2003).
} 


\section{B. The Benefits of a Critical Mass Diverse Classroom}

I operationalize critical mass by asking students about the benefits or participating in the classroom with students who shared their racial and ethnic background. I did not articulate a specific numerical threshold. However, I did ask students to provide a racial and ethnic demographic breakdown of a typical classroom population that they encounter.

Because the Grutter Court saw critical mass as essential to achieving the twin goals of increased racial understanding and the eradication of racial stereotypes, the same set of benefits are analyzed here as in the previous section. Therefore, the organizational presentation of the variables also mirrors the presentation in the preceding segment. I begin with the first Grutter goal of increased racial understanding and the related cognitive benefits. Next, I examine the second Grutter goal of the dissipation of racial stereotypes and the campus climate and stigma benefits associated with it. In addition, I added one more variable measuring social legitimation: increased self-confidence. ${ }^{132}$ One might anticipate that more students would report achieving the Grutter benefits when critical mass diversity is apparent in the classroom. ${ }^{133}$

\section{The Entire Sample}

Table Four presents the results. Only $40 \%$ of students in the sample stated that attending class with students of the same racial or ethnic background was important to them. ${ }^{134}$ More students ranked diversity as more important than racial similarity in the classroom.

\footnotetext{
${ }^{132}$ If a critical mass of students allows for minority students to move beyond their stereotype, one might predict that they would have increased confidence at school. See Nunn, supra note 58; see also STEELE, supra note 19, at 135 (arguing that critical mass could create a number at which minorities no longer feel identity threat-i.e., vulnerable to stereotypes, and feel comfortable in the classroom).

${ }^{133}$ The fact that critical mass is such an imprecise term vexes affirmative action opponents particularly. Steele, however, notes that it can vary from one setting to the next and can be overcome or influenced by other information. He and Purdy Vaughn found that low critical mass at a business could be overlooked if the company espoused a valuing diversity policy. Thus, cues in a particular context could neutralize a stereotype threat and generate an identity safe environment even without critical mass. STEELE, supra note 19 , at 148.

${ }^{134}$ Whether a student views being in a class with students of the same race as important is statistically significantly correlated with whether a respondent views same racial background classmates as providing any of the benefits articulated above. However, how one values critical mass did not lead students to self-select into states that allow or ban affirmative action. No correlation exists between where one attends school and their preference for similar racial background students. Furthermore, no correlation exists between whether one attends an $\mathrm{HBCU}$ or a predominantly white institution and how important a student views having students of the same racial background in his or her class. Thus, it is difficult to establish causation between these two variables. One may encounter the benefits of diversity and critical mass and then decide these
} 
Substantially fewer students reported that the presence of students of the same racial background achieved the first Grutter goal of increased racial understanding. For example, only one-quarter of the sample felt that the admission of more students of the same racial background increased positive interracial experiences for them inside and outside of the classroom. Similarly, increased positive crossracial experiences for other students seemed true for only $26 \%$ of the respondents.

The cognitive variables associated with increased racial understanding show limited enthusiasm as well. While only about one-quarter of the students reported that attending class with students of the same background led them to learn more, close to $40 \%$ of the students said that it increased their motivation. Moreover, a mere one-fifth of the students believed the presence of students of their same race in the classroom led white students to engage in perspective taking.

With regard to the campus-climate variables associated with the second Grutter objective-less racial stereotyping and a decrease in stigma-only one measure exceeded the $50 \%$ mark for "agree" or "strongly agree." More than half of the students felt more welcome on campus when students of their racial background attended their class. Slightly more than one-third of students perceived better interactions with their professors. Similarly, slightly less than one-third of students believed that the presence of students of the same background in their classroom decreased overt racism.

While the benefit of participating in a class with students who share a racial background appears to be associated with a decrease in stigma for only about onethird of the students, it does appear to increase self confidence for $40 \%$ of students. ${ }^{135}$ Less than one-third of students saw a decrease in internal stigma-i.e., the pressure to prove themselves because of their race. A little more than one-third of students stated that similarly raced students in the classroom decreased external stigma-i.e., other students questioning their qualifications. ${ }^{136}$

features are important. Conversely, one may decide that diversity and critical mass are important and then be readily disposed to find their benefits. The main point is that affirmative action does not determine which students valued having others of the same racial and ethnic background in their class and the benefits they viewed emerging from it.

135 This variable measures whether experiencing critical mass allows a student to identify as an individual who can participate freely in class and overcome stereotypes associated with his or her race.

136 These results, however, raise interesting questions about how critical mass may affect a student's psychological well-being in terms of performance in school because of stereotype threat. In other words, does critical mass play a role in making race less salient in classroom performance? In future research, I intend to examine how the sociological structure of the classroom may affect racial priming and, in turn, affect student performance. These results show increased self-confidence, but that doesn't necessarily translate into decreased or increased stigma. See Claude M. Steele, A Threat in the Air: How Stereotypes 
U N I V E R S I T Y O F P I T T S B U R G H L A W R E V I E W

PAGE

Table 4: Variables for Attending Class with Students of the Same Racial/Ethnic Background by Race

\begin{tabular}{|c|c|c|c|c|c|}
\hline & All & Afr. Am & Latino/a & Asian Am. & Multiracial \\
\hline $\begin{array}{l}\text { Student felt more } \\
\text { welcome on campus }\end{array}$ & $51.2 \%$ & 56.7 & 44.9 & 36.9 & 43.2 \\
\hline $\begin{array}{l}\text { Increase of student's } \\
\text { self-confidence }\end{array}$ & 40.4 & 45.9 & 44.9 & 31.6 & 24.3 \\
\hline Important to student & 40.1 & 45.6 & 32.2 & 36.8 & 36.8 \\
\hline $\begin{array}{l}\text { Student became more } \\
\text { motivated }\end{array}$ & 37.1 & 40.9 & 32.8 & 31.6 & 24.3 \\
\hline $\begin{array}{l}\text { Led to positive } \\
\text { interactions } \mathrm{w} / \text { professor }\end{array}$ & 34.7 & 38.4 & 31.1 & 26.3 & 27.0 \\
\hline $\begin{array}{l}\text { Decreased students' } \\
\text { pressure to prove } \\
\text { themselves because of } \\
\text { race or ethnicity }\end{array}$ & 34.3 & 39.3 & 29.8 & 21.0 & 29.7 \\
\hline Decreased overt racism & 31.6 & 38.2 & 27.6 & 15.8 & 33.4 \\
\hline $\begin{array}{l}\text { Decreased students' } \\
\text { qualifications being } \\
\text { questioned }\end{array}$ & 31.5 & 39.5 & 28.0 & 10.5 & 24.3 \\
\hline $\begin{array}{l}\text { Increased positive cross- } \\
\text { racial experience for } \\
\text { student inside the } \\
\text { classroom }\end{array}$ & 26.6 & 24.8 & 34.4 & 26.4 & 26.3 \\
\hline $\begin{array}{l}\text { Increased students' } \\
\text { learning ability }\end{array}$ & 26.0 & 26.4 & 27.2 & 36.9 & 18.4 \\
\hline $\begin{array}{l}\text { Led to positive inter- } \\
\text { racial experiences for } \\
\text { other students }\end{array}$ & 25.0 & 23.1 & 29.3 & 26.3 & 24.3 \\
\hline $\begin{array}{l}\text { Led to white students' } \\
\text { perspective taking }\end{array}$ & 20.3 & 19.2 & 22.8 & 31.6 & 22.2 \\
\hline
\end{tabular}

Shape Intellectual Identity and Performance, 52 AM. PsYCHOLOGIST 613 (1997) (demonstrating that highly domain-attached individuals are at highest risk for the negative effects of stereotype threat). 


\section{Critical Mass Benefits in Affirmative Action vs. Anti- Affirmative Action States}

It is here where we arrive at the essence of the Grutter case. Does affirmative action work in tandem with critical mass to realize the benefits the Supreme Court rationalized as compelling? Indeed it does, but not very effectively.

Unlike the comparison between affirmative action and anti-affirmative action states on the benefits of diversity generally, statistically significant differences do emerge on the benefits of critical mass and an institution's policy on race-based admissions.

Table Five reveals the results. Under Grutter, affirmative action states would be more likely to achieve a critical mass of students. ${ }^{137}$ And as a consequence, more students in affirmative action states would report benefits associated with the presence of students of the same race or ethnic background in their classes. Indeed, a statistically significant, but moderate, correlation exists between the percentage of students in a class of the same race as a respondent and whether that respondent attends school in a state with race-based admissions. ${ }^{138}$ Conversely, a small, but statistically significant, difference exists as to the percentage of white students that students of color will encounter in their class and the state where they attend school. Specifically, students in affirmative action states will likely see a smaller percentage of white students in their classes compared to students in antiaffirmative action states. ${ }^{139}$ These correlations suggest that any increase in the number of students reporting benefits in affirmative action states versus states that bar affirmative action might be attributable to affirmative action classroom settings achieving critical mass for certain students of color. ${ }^{140}$ However, there is no cause

\footnotetext{
${ }^{137}$ What we do not know is what that critical mass number is from campus to campus or classroom to classroom.

${ }^{138}$ The Pearson's R - the correlations coefficient that measures the association between two variablesis .320 with a statistical significance of $\mathrm{p}<.001$.

139 The Pearson's R is -.207 with a statistical significance at the $\mathrm{p}<=.01$ level. The negative correlation exists because the race-based admissions variable is a dummy variable in which anti-affirmative action states were coded as " 0 " and affirmative action states were coded as " 1. "

${ }^{140}$ As a number of statistically significant associations were established between the critical mass benefits and affirmative action versus anti-affirmation action states, I thought it was valuable to determine if any of those relationships were spurious. In other words, was the relationship between these two variables masking another variable? In particular, because the variable "having students with the same racial background in my class is important to me" is so strongly correlated with each of the benefits, I controlled for it by running the correlations between the benefits and state where one attends school. The results show that where a relationship exists between a reported Grutter benefit and the state
} 
U N I V E R S I T Y O F P I T T S B U R G H L A W R E V I E W

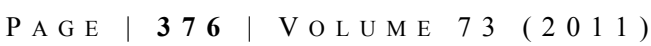

Table 5: Variables for Attending Class with Students of the Same Racial/Ethnic Background by Affirmative Action States or Not

\begin{tabular}{|l|c|c|}
\hline & $\begin{array}{c}\text { Anti-Affirmative } \\
\text { Action }\end{array}$ & Affirmative Action \\
\hline Student felt more welcome on campus & $40.3 \%$ & $51.6^{*}$ \\
\hline Increase of student's self-confidence & 29.0 & $40.2^{*}$ \\
\hline Important to student & 35.1 & 37.1 \\
\hline Student became more motivated & 29.0 & 40.2 \\
\hline Led to positive interactions with professor & 29.0 & $34.0^{*}$ \\
\hline $\begin{array}{l}\text { Decreased students' pressure to prove } \\
\text { themselves because of race or ethnicity }\end{array}$ & 30.7 & $37.1^{*}$ \\
\hline Decreased overt racism & 23.7 & $34.7^{*}$ \\
\hline $\begin{array}{l}\text { Decreased students' qualifications being } \\
\text { questioned }\end{array}$ & 22.4 & $35.6^{*}$ \\
\hline $\begin{array}{l}\text { Increased positive cross-racial experience } \\
\text { for student inside the classroom }\end{array}$ & 18.6 & 23.7 \\
\hline Increased students' learning ability & 26.0 & 31.6 \\
\hline $\begin{array}{l}\text { Led to positive interracial experiences for } \\
\text { other students }\end{array}$ & 26.7 & 33.1 \\
\hline Led to white students' perspective taking & 27.7 & \\
\hline
\end{tabular}

for celebration. The results still show weak enthusiasm around the Grutter benefits.

In fact, beginning with the first Grutter objective, only one variable shows a statistically significant difference: Seventeen percent more students in affirmative action states report an increase in the positive cross-racial experiences inside the classroom when students of their same race are in their class.

None of the cognitive benefits revealed any statistically significant differences between students in affirmative action states and those in states that bar race-based admissions.

where one attends school, that relationship becomes even more pronounced when controlling for whether having similar racial backgrounds is important to a student. In other words, the importance variable does not hold sway over the relationship between affirmative action and the benefits of critical mass. Thus, affirmative action institutions seem to offer a landscape of critical mass that permits the Grutter benefits to shine through for a small portion of students. And, in turn, those students come to view having people of the same racial or ethnic background in their classes as important to them. The significance of this result will be explored further in Part V. 
However, attending classes in which a respondent found students of the same race or ethnic background as him or herself had a statistically significant effect on the second Grutter aim of reducing racial stereotypes. Moreover, a reduction in racial stereotyping appeared to improve the campus-climate experiences more so for students in states that allow race-based admissions. First, more than half of affirmative-action-state students agreed or strongly agreed compared to $40 \%$ of anti-affirmative-action-state students that such a classroom environment made the student feel more welcome on campus. Furthermore, 34\% of affirmative-actionstate students compared with $29 \%$ of anti-affirmative-action state students reported that shared racial backgrounds in the classroom led to positive interactions with professors. Perhaps most striking is that this type of classroom environment decreased overt racism for $11 \%$ more students in affirmative action states than students in anti-affirmative-action states experienced.

Similarly, attending class with students of the same race is associated with a statistically significant reduction in both of the stigma variables. Specifically, sharing a classroom with people of the same race led students in affirmative action states to report a reduction in external stigma at a rate $11 \%$ higher than antiaffirmative-action-state students. Moreover, statistically significant differences emerge for students in in affirmative action states: students in affirmative action states are $7 \%$ less likely to experience internal stigma than students in antiaffirmative action states, while $11 \%$ more felt increased self-confidence in affirmative action states.

The results reveal a small glimmer of hope for under-represented minority science majors' ability to achieve the Grutter goals in a diverse classroom. Unfortunately they are achievable for too few students. Institutions of higher learning must create a particular type of diversity - functional diversity - in order to have any hope of obtaining its attendant benefits. Critical mass alone cannot do the job. In this next part, I consider these results in light of the criticisms and predictions made in the shadow of Grutter.

\section{Discussion}

The results demonstrate that diversity alone provides benefits for few students of color. Moreover, affirmative action appears to play a marginal role, if any at all, in the idea of diversity and the fruition of the Grutter benefits. The first part of this section explores why that might be so. The results also reveal that critical mass diversity offers some Grutter benefits and certainly more so for students in affirmative action states, but the same theme remains. Too few students actualize these benefits even under a so-called critical mass regime. In the second part of this segment, I ruminate on some reasons for this phenomenon. I argue that institutions are over-reliant on critical mass, an amorphous concept that should be phased out. Furthermore, I argue that institutions engage in mendacity when they operate in a 
U N I V E R S I T Y O F P I T T S B U R G H L A W R E V I E W

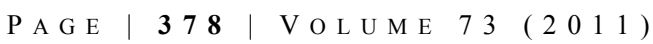

culture of colorblindness. It is a disservice to all their students. Finally, in the third part, I introduce the idea of a Contextualized Contingencies Model. I argue that affirmative action is a vibrant and necessary policy that, when employed in a colorconscious institution, with other effective devices, makes attainable Grutter's noble intentions.

\section{A. Diversity Benefits}

This study set out to answer the question of whether students of color enjoy the benefits of diversity as articulated in a race-neutral Grutter model of affirmative action. Two major aspirations emerge when considering how diversity is supposed to affect higher education. ${ }^{141}$ First, a diverse classroom will promote cross-racial understanding. ${ }^{142}$ It is probably fair to say that this aim applies to both white students and students of color. ${ }^{143}$ Second, a diverse classroom will result in the "breaking down of stereotypes." 144 It is equally fair to say that students of color stand to gain from the breakdown of stereotypes. ${ }^{145}$ Let us examine whether either of these objectives were met for students of color in a diverse classroom.

It is heartening that regardless of whether one attends school in an affirmative action state, the majority of students perceive some benefits from diversity. In this sense, critics from both sides of the camp can feel some solace in knowing that diversity can play an important role in education.

These results suggest that both students of color and white students stand to benefit from interacting with diverse individuals in the classroom. Aside from Asian students, white, Latina/o, and African American students find themselves

\footnotetext{
${ }^{141}$ While Grutter articulated a third benefit of preparing students for an increasingly diverse workforce, this benefit seems to be a derivative of the first two. Grutter v. Bollinger, 539 U.S. 306, 330 (2003).

${ }^{142} I d$. Yet critics express concern that diversity is for the good of white students exclusively. See Nunn, supra note 58 , at 724 .

${ }^{143}$ A 2003 study confirms that Whites are the most segregated group in the nation's public schools. On average, the student population is $80 \%$ white. ERICA FranKENBERG ET AL., HARVARD UNIV. CIVIL Rights Project, A Multiracial Society with Segregated Schools: Are We Losing the DREAM? (2003), available at http://pages.pomona.edu/ vis04747/h21/readings/AreWeLosing theDream.pdf. Conversely, Reuters reported last year that school segregation is at its lowest rate since the Civil Rights era, with African Americans and Latina/os increasingly isolated in schools. Matthew Bigg, U.S. School Segregation on the Rise: Report, REUTERS, Jan. 14, 2009, available at http://www.reuters.com/article/ idustre50d7cy20090114.

${ }^{144}$ Grutter, 539 U.S. at 330.

${ }^{145}$ See generally STEELE, supra note 19.
} 
increasingly segregated in elementary and secondary education. ${ }^{146}$ Thus, diversity, as a concept, is relevant in higher education. Structural diversity allows for contact.

The results of this study alleviate the concern as to whether students of color would experience the first Grutter benefit, yet the data certainly do not assuage concerns respecting the second goal: the breaking down of stereotypes. ${ }^{147} \mathrm{We}$ might expect to see a reduction in external and internal stigma as high on the list of benefits students of color encounter in a diverse classroom. In fact, we might even anticipate that more students in states where the Grutter model of affirmative action is employed would report decreases in stigma as a benefit of diversity. But we do not.

First, it is important to consider the sample that is reporting the increased racial understanding. Students of color are gaining understanding of other racial or ethnic groups, but this report does not necessarily translate into other racial or ethnic groups understanding and transforming their behavior. ${ }^{148}$

For example, a review of the varied racial-group responses to these benefits reveals how students from different racial or ethnic groups experience diversity. Specifically, African Americans are least likely to report any benefits, while Latina/os are more enthusiastic about these benefits. ${ }^{149}$ The variation in response occurs because of the contextualization of race. A multitude of histories and legacies of race and ethnicity exist. ${ }^{150}$ Because race and ethnicity are socially constructed, ${ }^{151}$ different racial and ethnic groups each carry different vestiges of

\footnotetext{
${ }^{146}$ See FrANKEnBERg ET AL., supra note 143, at 27.

${ }^{147}$ The breaking down of stereotypes is also encapsulated in the functions of diversity that Carbado and Gulati have articulated. Carbado \& Gulati, supra note 14.

${ }^{148}$ John Calmore questions whether Whites are able to remove their color gaze and develop true empathy and connection with people of color. CALMORE, supra note 41 , at 74 . The results of the study suggest that students of color do not have great confidence in white students' ability to do so. That raises the question of what exactly is racial understanding.

${ }^{149}$ See infra Table 2.

${ }^{150}$ Charles Ogletree, The Presumption of Guilt: The Arrest of Henry Louis Gates JR. AND RACE, Class, AND CRIME IN AMERICA 99 (2010).

${ }^{151}$ Social scientists assert that race is a social construct. By that, they mean values and ideas about race arise and perpetuate themselves through social situations. As Montejano aptly puts it, "Although race situations generally involve people of color, it is not color that makes a situation a racial one.... [T] he race question ... represents an arena of struggle and accommodation .... [I]t comes into being when ideas and sentiments are publicly articulated and institutionalized." DAVID MONTEJANO, ANGLOS AND MeXiCANS IN THE MAKING OF TeXAS, 1836-1986, at 4-5 (1987).
} 
U N I V E R S I T Y O F P I T T S B U R G H L A W R E V I E W

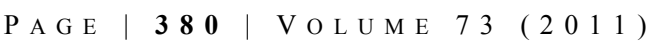

status and power. Society bequests an unwanted inheritance on students of color that mediates how they experience a diverse classroom environment.

Nowhere is the racial hierarchy more apparent than in the diverse classroom. Almost uniformly, statistically significant differences exist between African American students and Latina/o students regarding the perceived Grutter benefits. Consistently, Latina/o students report benefits at greater rates than the entire sample, and African American students report benefits at much lower rates than Latina/o students and lower rates than the entire sample.

These racial and ethnic differences echo the results in other studies. ${ }^{152}$ In fact, Ogbu's ${ }^{153}$ comparative educational theory of minorities, and more recently McClelland's work on the integration of minority students onto predominantly white campuses, may explain this divergence. ${ }^{154}$ Students from involuntary minority groups, meaning enslaved racial groups, compared to voluntary minority groups who immigrated to a host country by choice, viewed race relations more negatively than students from voluntary minority groups. Race relations were defined by white students' attitudes about minorities. This point emphasizes the importance of treating racial and ethnic diversity differently from other types of diversity. The social meanings attached to one's race carry significance in ways that simply do not compare to other types of diversity that either Justice O'Connor or campus admissions officers can dream up. Much more is at stake with racial diversity.

Second, recall that Gottfredson et al. found that the benefits of diversity are most apparent with content diversity. ${ }^{155}$ Content diversity refers to course curriculum, which includes content that addresses issues related to race and ethnicity. As Gottfredson observed, "[M]ere compositional diversity is not sufficient (but is necessary) for reducing prejudice." 156 In other words composing a diverse classroom will not reduce prejudice or stereotyping. In fact, if students of

\footnotetext{
${ }^{152}$ See, e.g., John Matlock, Student Expectations and Experiences: The Michigan Study, DivERSITY DIGEST, http://www.diversityweb.org/digest/Sm97/ research.html (last visited Apr. 9).

153 John Ogbu, Minority Education and Caste: The American System in Cross Cultural PeRSPECTIVE (1978).

${ }^{154}$ Katherine McClelland, Paper Presented at the Annual Meeting of the American Sociological Association: How Race Matters: The Integration of Immigrant and Involuntary Minorities on a Predominantly White College Campus (Aug. 16, 2003).

${ }^{155}$ Gottfredson et al., supra note 23, at 93.

${ }^{156} I d$.
} 
color find themselves in racial or ethnic isolation in a diverse classroom, the burden of tokenism is just as heavy as if they were the only person of color in the classroom. Equally important, though, is that most courses don't include a curriculum on race issues - the type of diversity that may reduce prejudice. Structural diversity - the type of diversity contemplated by Grutter - is impotent, without more, when it comes to succeeding in executing on the benefits Grutter imagined: increasing racial understanding and decreasing racial stereotypes.

Third, structural diversity - putting students of varying racial or ethnic groups in a class where they do not have a history of experience interacting with each other - puts all students at risk for alienation. ${ }^{157}$ In particular, white students, lacking the skills to interact with students of different backgrounds, can respond in such a way that inadvertently leads to increased racial tension and stereotype threat. ${ }^{158}$ For example, Apfelbaum found that white individuals, particularly those concerned with not appearing prejudiced, engage in colorblind behavior even when recognition of race differences is appropriate. ${ }^{159}$ The result is that Whites intending to create a positive interracial interaction end up generating the opposite. ${ }^{160}$

In the college classroom, white students may attempt to engage in colorblind behavior to avoid appearing biased, but in doing so, their behavior comes across as unfriendly and nonverbal. Students of color, particularly African-American students, interpret these actions as evidence of prejudice. ${ }^{161}$ In turn, the colorblind behavior of white students, perceived as racism by students of color, heightens the threat of stereotype for minority students. ${ }^{162}$

Finally, the destruction of stereotypes for minority students requires that students take on and be open to other individuals' perspectives. However, the results of the study reveal that only a slim minority of students of color believes that a diverse classroom leads to white students actually engaging in perspective taking. The opportunity for perspective taking, though, has to be navigated very carefully.

\footnotetext{
${ }^{157}$ STEELE, supra note 19 , at 191-210.

${ }^{158} \mathrm{Id}$.

159 E.P. Apfelbaum, S.R. Sommers \& M.I. Norton, Seeing Race and Seeming Racist? Evaluating Strategic Colorblindness in Social Interaction, 95 J. PERS. \& Soc. PSYCH. 918 (2008).

${ }^{160} \mathrm{Id}$.

${ }^{161} I d$.

${ }^{162}$ Steele, supra note 69.
} 


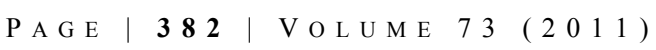

A phenomenon that does not appear to receive as much attention as minority stereotype threat is that white students are just as vulnerable to stereotype threat. However, white student responses to their own stereotype threat can lead to deleterious results in a classroom setting. Two studies reveal how a diverse student class can result in negative racial effects. Specifically, Vorauer and Turpie found that white students, normally ranked as low on a prejudice scale, reacted negatively to stigmatized groups of color when the white students believed they were being evaluated in terms of their privileged social position. ${ }^{163}$ In a second study, Goff et al. found that when white students feared a stereotype threat of appearing racist, they engaged in more distance from their black counterparts. ${ }^{164}$ Thus, merely creating diversity under an affirmative action program (or not) does little to achieve the Grutter benefits. Well thought out interactions in the classroom are as essential for minorities as they are for Whites. ${ }^{165}$

Some might see as vital the question: if affirmative is a compelling state interest, why are no statistically significant differences present between students in affirmative action and anti-affirmative action states on the benefits of being in a classroom with diverse others? Relying on the concept of diversity alone, one might hypothesize that greater, statistically significant numbers of students of color in institutions that allow for race-based admissions would report accruing these benefits. ${ }^{166}$ However, to confuse the concept of diversity with a concentration of minority students rather than a student's own racial group is to fall into the fallacy

${ }^{163}$ Jacquie D. Vorauer \& Cory A. Turpie, Disruptive Effects of Vigilance on Dominant Group Members' Treatment of Out Group Members: Choking Versus Shining Under Pressure, 87 J. PERS. \& SOC. PsYCH. 384 (2004) (presenting research showing that white students who felt that stigmatized groups were judging white student behavior because of their perceived status and power in society were more likely to react negatively to stigmatized minorities).

${ }^{164}$ Phillip Atiba Goff et al., The Space Between Us: Stereotype Threat and Distance in Interracial Contexts, 94 J. PERS. \& SOC. PSYCH. 91 (2008).

${ }^{165}$ As Calmore notes, Whites are raised to talk about race in such a way that maintains the status quo. Strategies are adopted so that Whites do not have to engage in the exercise of considering how they perpetuate a racial hierarchy that secures their position at the top. The strategies include semantic evasion and semantic infiltration. CALMORE, supra note 41, at 79. So one can imagine how threatening it can be to confront one's privilege after a lifetime of what I call "racialized muting." Gallagher observes that the common sense view of race relations is to acknowledge race, perhaps, from a cultural perspective, but not to actually discuss race. Charles A. Gallagher, Color-Blind Privilege: The Social and Political Functions of Erasing the Color Line in Post Race America, 10 RACE, GENDER \& CLASS 4 (2003).

166 The data in this study suggest a correlation between affirmative action states and increased racial diversity, but that does not necessarily lead to increased access to Grutter benefits. 
of the monochrome diversity paradigm. ${ }^{167}$ That is to say, a student of color can be racially isolated and, yet, still be in a racially diverse classroom. Thus, when diversity offers nothing more than a landscape, a student risks racial isolation equally in affirmative action and anti-affirmative action institutions. ${ }^{168}$ Diversity, for students of color, exists in both types of institutions.

The great hope of Grutter was, as Michigan argued and the Court recognized, racial understanding and demolished stereotypes. Yet it demanded a special type of diversity - critical mass diversity. However, as the results of the study show, even critical mass diversity is lacking. The next section addresses why.

\section{B. Critical Mass}

Students express even less enthusiasm when asked about the benefits associated with learning in a classroom with at least some students of the same racial or ethnic background as their own. While statistically significant differences are apparent between students in affirmative action and anti-affirmative action states on virtually every measure, far less than the majority of students profited from these benefits.

The lack of enthusiasm regarding the benefits associated with having people of the same racial background in class may occur for a number of reasons. Recall that critical mass is an amorphous concept resistant to fixed clarity. First, sameness does not equate with critical mass. The danger of creating diversity is assuming it creates critical mass by default. Without critical mass, affirmative action supporters worry that students of color are nothing more than tokens, available to educate the white majority. Having to "perform" diversity is problematic. Even Justice Thomas expressed as much. ${ }^{169}$

Second, Michigan and the Supreme Court deemed critical mass as important for minority students. Yet students do not define what that means. As administrators, not students, make admissions decisions, it is quite possible that even with the best of intentions, affirmative action institutions have neither the complex expertise to know what would make effective numbers, nor are they fully

\footnotetext{
${ }^{167}$ Monochrome diversity refers to the idea that having any students of color in a classroom, regardless of how many members of a particular ethnic group might be present, creates diversity. In other words, diversity just refers to non-white students in the classroom.

${ }^{168}$ Racial isolation can actually increase the risk of harm to students of color because of greater incidents of stigma and racial hostility. Bowen, supra note 13.

${ }^{169}$ Nunn, supra note 58, at 722-23; Rodriguez, supra note 67, at 6-7; Grutter v. Bollinger, 539 U.S. 306, 372-73 (2003) (Thomas, J., concurring in part and dissenting in part).
} 
prepared to admit students of color at the rates required to achieve a theoretical critical mass. ${ }^{170}$

In this study, I asked students to describe their ideal classroom environment. Students provided a percentage breakdown of a variety of racial and ethnic groups that overwhelmingly looked like this: 20\% African American, 20\% Asian, 20\% Hispanic, $20 \%$ Other, ${ }^{171}$ and $20 \%$ white. ${ }^{172}$ Thus, a student of color's perception of diversity looks radically different from how administrators of these elite institutions envision diversity. But is it critical mass? ${ }^{173}$

Unlike the monochrome model of diversity - white students and non-white students - these students see equal concentrations of different ethnic groups as a pre-cursor to achieving a diverse classroom. White students are no longer in the majority. Minority students are no longer in the minority.

In actuality, these students may be changing the topography of the diversity landscape, but it will not necessarily lead to functional diversity. ${ }^{174}$ This conception is consistent with Contact Theory. ${ }^{175}$ The out-group - in this case, students of color-must have equal social standing as the in-group: white students. However, numbers do not equate to social standing. The challenge here is relying on

170 See Delgado, supra note 63 (arguing that affirmative action is a majoritarian device). See also STEELE, supra note 19 (pointing out that it is an imprecise term that is highly situational). Ideally, a classroom should have enough students of a particular racial or ethnic background to alter the racial hierarchy, power structure, status, and threat of stereotype for minority students. Id. However, how can administrators predict such a formula? Hackman and Allmendinger attempted to identify some effective-sense critical mass by studying gender in symphonies worldwide. Their results showed that women at $10 \%$ of the population felt tokenism and at $20 \%$ felt fractiousness. Not until the number reached $40 \%$ did women report satisfying experiences in the symphonies. Jutta M. Allmendinger \& J. Richard Hackman, The More the Better? A Four-Nation Study of the Inclusion of Women in Symphony Orchestras, 74 SOC. FORCES 423 (1995).

${ }^{171}$ Some respondents did not use this category, but rather replaced it with Native American, East Indian, Middle Eastern, Southeast Asian, or some combination.

${ }^{172}$ This demographic breakdown was consistent across race and ethnicity, gender, state where one attended school, and whether one attended an HBCU.

${ }^{173}$ I conducted an analysis to determine if a correlation existed between the number of students of color in a student's class and the increase in reported Grutter benefits. No such correlation exists. These results are consistent with Gottfredson's work. Structural diversity will not lead to the type of benefits Justice O’Connor envisioned.

${ }^{174}$ Carbado \& Gulati, supra note 14.

${ }^{175}$ ALLPORT, supra note 26, at 41 (noting that an in-group always implies the existence of an out-group and the possibility of hostility); Pettigrew \& Tropp, supra note 28 , at 1 (noting that intergroup contact typically reduces intergroup prejudice, though equal status between groups is prerequisite). 
mythical, variable, and, dare I say, ineffective numbers to achieve a massive cultural institutional shift. That is what is required to obtain equal social standing between students of color and white students.

I posit that like the other limits of Grutter, most particularly, achieving the benefits articulated in Grutter, institutions are not capable and do not possess the expertise to create equal social standing. ${ }^{176}$ Regrettably, in Justice O'Connor's majority opinion, she socially constructed a paradigm of diversity that pits one group as the producers of diversity and the other group as the consumers of it. ${ }^{177}$ As Hutchison wryly observes, it is one thing to do racial justice, it is another to selfportray racial justice such that it perpetuates the racial hierarchy:

It appears that society's elites demand that encounters with race (particularly when encountering blacks and Hispanics) remain consistent with the notions of minority inferiority and elite privilege. The transmutation of diversity programs into a form of cosmopolitanism allows university administrators to trumpet their commitment to racial justice without revolutionizing their educational policies to reflect it. $^{178}$

All is not lost. Institutions can do racial justice - if they choose. Remarkably, the strongest and most consistent predictor of whether respondents agreed or strongly agreed that they enjoyed the Grutter benefits was that they stated is was important to them to have individuals of the same race or ethnicity around them. Moreover, the power of this relationship became even more pronounced when I eliminated the possibility of bias. In other words, I removed the idea that students who reported these benefits purposely sought out diversity and chose to attend affirmative action institutions in order to get these benefits. Because this bias does not exist, we can suppose that, for a small portion of students, affirmative action

\footnotetext{
${ }^{176}$ Henze observes that even after integration emerged from Brown v. Board of Education, fractiousness, identity opposition, and racial tension actually increased. ROSEMARY HENZE ET AL., LEADING FOR Diversity: How SChoOl Leaders PRomote Positive InTERETHNic Relations 35 (2002).

${ }^{177}$ Cedric M. Powell, Rhetorical Neutrality: Colorblindness, Frederick Douglass, and Inverted Critical Race Theory, 56 CLEV. ST. L. REV. 823, 860 (2008) (arguing that Justice O’Connor analyzed the viability of affirmative action in terms of accommodating white interests and the benefits of institutions and corporations completely consistent with Derrick Bell's Interest Convergence Theory).

${ }^{178}$ Harry G. Hutchison, Moving Forward? Diversity as a Paradox? A Critical Race Review, 57 CATH. U. L. REV. 1059, 1086-87 (2008).
} 
provided a landscape of some sort of valued critical mass and allowed for the Grutter benefits to shine through. ${ }^{179}$

However, I suspect that for these students, it was not the structure of a miraculous formula of critical mass that empowered racial understanding and decreased stereotypes, but rather it was their environment that created contextualized contingencies.

Critical mass is a flawed concept not only because the notion is amorphous and highly situational, but also because of two other environmental factors in institutions of higher learning. I discuss these ideas below.

\section{Contextualized Contingencies Model}

Let me begin by positing that the Grutter benefits are rather modest goals. In this section, I return to a theme addressed earlier in the paper: functional diversity. ${ }^{180}$ In working towards this latter aspiration (which incorporates the Grutter goals) I contend that the intersection of colorblindness and the focus on a nebulous concept of diversity largely make critical mass immaterial. Instead, institutions of higher education might consider a new model that includes race consciousness and awareness of active and passive cues in the environment that are as varied as the students it admits. And then do something about it.

Keeping in mind that Carbado and Gulati define racial diversity, in part, as a relationship that exists between race and social experiences, ${ }^{181}$ it strikes me as imperative that educational institutions revolutionize their cultural thinking into one of color consciousness. Understanding color consciousness requires acknowledgement of the contextualized nature of every racial interaction. It allows for the recognition of different legacies and histories that have shaped and continue to shape what students will become. Quite literally, it means students must look at and acknowledge that another student's skin color tells a story -an ongoing narrative.

\footnotetext{
${ }^{179}$ Remember, too, that no relationship exists between the variable "important to me" and whether one attends an HBCU, traditionally white institution, or a school in an affirmative action state. Hence, students do not self-select into an environment that will increase their chances of encountering other students of the same race because they have decided prior to college-application time that diversity is important to them. Accordingly, it is possible that students who report having students of the same race in their class as important do so precisely because they have enjoyed the benefits of critical mass at some point in their educational careers. They most likely encountered those benefits in affirmative action states.

${ }^{180}$ Carbado \& Gulati, supra note 14.

${ }^{181} I d$.
} 
Functional diversity (and the more modest Grutter benefits) falls short because of the absence of recognized racial (and gender) context. Lack of context is the key tenet of colorblindness. It results in missed comprehension of social meanings, exclusion, alienation, and silencing. ${ }^{182}$ Colorblindness renders skin color irrelevant. As harmful as it is for students of color to have their narratives silenced, colorblindness allows nonminority students (perhaps unwittingly) to inflict even more damage. In our post-race world, skin color should not be acknowledged, for fear of appearing racist. The effect is that nonminority students, as discussed above, lack the skills to engage with students of color, generally, and on more racially contextualized topics, specifically. As Charles Gallagher observed in his study on the social and political functions of colorblindness, this is a common-sense understanding of race relations. It allows for contemporary race relations to be viewed as a clean slate, with all groups on a level playing field. ${ }^{183}$

It is injurious to situate the diversity model, which is largely rationalized as a benefit to all, into a campus milieu that espouses colorblindness, consciously or subconsciously. ${ }^{184}$ It reinforces the idea that neither the institution nor the individual actors within need concern themselves with race or its consequences. William Julius Wilson confesses that he used to espouse the strategy employed by the proponents of affirmative action under the diversity model. However, he has reversed his course precisely because such a strategy avoids the frank and necessary conversations about the barriers privileged members of society erect and protect against people of color. ${ }^{185}$

Furthermore, diversity in a colorblind society creates invisibility. While it allows privileged members of an academic institution to occasionally engage in the classroom without disrupting their status, it also allows these students to disengage outside of the classroom. It creates a schizophrenic environment in which race is

${ }^{182}$ Bowen, supra note 13 , at 1235.

${ }^{183}$ Gallagher, supra note 165.

${ }^{184}$ In fact, Richeson and Nussbaum found that when college students were primed for multiculturalism versus colorblind ideologies as ways to improve interethnic relations, students exhibited more bias in a colorblind ideological approach. Jennifer Richeson \& Richard Nussbaum, The Impact of Multiculturalism Versus Color-Blindness on Racial Bias, 40 J. EXPERIMENTAL PSCYHOL. 417 (2003).

${ }^{185}$ William Julius Wilson, More than Just Race: Being Black AND PoOR IN THE INNER City 141 (2009). 
U N I V E R S I T Y O F P I T T S B U R G H L A W R E V I E W

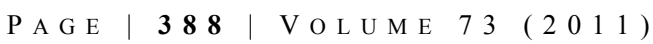

consumed for education but otherwise ignored. As this study shows, structural and content diversity do not translate into every classroom. ${ }^{186}$

Fine, Weis \& Powell presciently observed in 1997 that Allsport's Contact Theory was futile in the classroom because any attempt to create equality in a temporary setting like school did not acknowledge the larger contexts outside the classroom from which many students must navigate on a daily basis. They warned that without this recognition of structural racialized and economic difference, full and meaningful engagement amongst a diverse student body would undermine the goals of diversity in the first place. ${ }^{187}$

Colorblindness's functionality as a way to minimize conflict and discomfort actually does the opposite. The inclination for some white students wanting to appear as unbiased is to ignore racial differences. Yet colorblindness causes racial distance. Racialized mutism - the unwillingness to discuss racial stratificationcreates more damage. Plaut et al. found that when Whites engage in colorblindness, it "reinforces majority dominance and minority marginalization." ${ }^{188}$ To take a page out of Bell's Interest Convergence Theory, Whites actually need assurance that to recognize the contextualization of race is vital to their own educational and economic success. $^{189}$

Without contextualization, colorblind "diversity," as Bell notes, sidesteps the larger societal structural barriers that individuals must overcome before they ever arrive on campus. Allen warns:

Any attempt to address the problems faced by African American college students without considering the broader context of issues confronting Blacks as a discriminated minority in America is doomed to fail, for the experiences of

\footnotetext{
186 These results are consistent with other studies that have shown diversity alone cannot create meaningful educational outcomes. Campus climate and institutional support are also required. Gary Pike \& George Kuh, Relationships Among Structural Diversity, Informal Peer Interactions and Perceptions of the Campus Environment, 29 REV. HIGHER EDUC. 425 (2006).

${ }^{187}$ Michelle Fine et al., Communities of Difference: A Critical Look at Desegregated Spaces Created for and by Youth, 67 HARV. EDUC. REV. 247, 247 (1997).

188 Victoria Plaut, Kecia Thomas \& Matt Goren, Is Multiculturalism or Colorblindness Better for Minorities?, 20 PsYCHOL. SCI. 444, 445 (2009).

${ }^{189}$ Bell, supra note 20, at 523 .
} 
Black students in higher education are in part products of larger systematic problems. ${ }^{190}$

To be sure, revolutionizing institutions to become color conscious will be met with resistance, but it is achievable. Expecting an enigmatic critical mass to solve the issues of dysfunctional diversity is a failure in which the train has already left the station. ${ }^{191}$

Consider again, Carbado and Gulati state that every one of their diversity functions derives from a relationship between social experience and race. More specifically, how we experience, think about, and conduct ourselves in society is shaped, though not determined, by our race. ${ }^{192}$

The colossal challenge is coming to a place where people feel safe about acknowledging and confronting contextualized identities - not only others', but their own. Claude Steele cautions, "unless you make people feel safe from the risk of these identity predicaments in identity integrated settings, you won't succeed in enabling people from different backgrounds to work comfortably together." ${ }^{\text {193 }}$ In other words, without contextualization, we are unlikely to achieve Grutter's first goal of increased racial understanding.

This is precisely where part two of the Contextualized Contingencies model comes in to play. Once institutions are prepared to implement a cultural shift towards color consciousness, a number of simple steps come into play that can have life-altering consequences for students, faculty, and administration alike.

Perhaps in few other institutions are our identities as invested as in school or work. We bring a lifetime of adaptation to our identities when we arrive at school. For each and every student, as she or he enters the "hallowed halls" of academia, contingencies exist - circumstances that make that particular person's identity relevant and something that may have to be managed. ${ }^{194}$ Erving Goffman called these identities master statuses, as they are the lenses through which others determine how and whether to interact with us. ${ }^{195}$

\footnotetext{
${ }^{190}$ Walter R. Allen, The Color of Success, 62 HARV. EdUC. REV. 26, 42 (1992).

${ }^{191}$ See supra Part IV.

${ }^{192}$ Carbado \& Gulati, supra note 14.

${ }^{193}$ STEELE, supra note 19 , at 215.

${ }^{194}$ Id. at 83.

${ }^{195}$ GOFFMAN, supra note 42.
} 
U N I V E R S I T Y O F P I T T S B U R G H L A W R E V I E W

PAGE

Contextualization allows each of us to recognize that we have identities or master statuses. But then what? Both Steele, the social psychologist, and Goffman, the sociologist, agree that students and faculty alike are examining social cues. Goffman observed that the cues are both active and passive, but the point is that in any given setting an individual can feel identity threat - a fear of being judged based on a stereotype and the very issue Grutter sought to remediate with its second benefit.

Thus, step one is to understand the power of social cues in an environment. Remaining with the theme of colorblindness and white resistance to discuss issues of race for fear of others labeling them as racist, ${ }^{196}$ a simple change in social cues can change white students' response and openness to racial understanding and stereotyping. For example, Plaut et al. found that non-minorities view multiculturalism as exclusionary to them, but with institutional diversity efforts, non-minorities can come to view diversity as inclusionary. ${ }^{197}$ Moreover, Steele et al. found that presenting white students who may feel fear of being viewed as racist-i.e., a negative stereotype threat - with a social cue that suggests the experience they are about to engage in is a learning experience, significantly reduced the threat. ${ }^{198}$ Conversely, simply telling students to trust that they won't be judged was not enough to overcome the threat. ${ }^{199}$

Therefore, step two is to get faculty, administrators, and students to comprehend that seemingly innocent and inadvertent social cues have powerful effects to build trust or dismantle it. Students scan a setting for social cues. Are there other students, professors, or administrators that look like me? Does the school take a normative approach that expects varied discussion in class? How are student ideas valued in and out of class? What types of courses are offered? Who gets research assistantships? Who gets supported through scholarships? What facial expressions do professors expose when interacting with certain students? Does my background bring meaning to this institution? How do students interact with each other? A careful study of Carbado and Gulati's functional diversity suggests that

\footnotetext{
${ }^{196}$ STEELE, supra note 19, at 202-06 (finding that white students arranged chairs further away from their black counterparts when they believed they would be discussing racial profiling versus love and relationships).

197 Victoria C. Plaut et al., “What About Me?” Perceptions of Exclusion and Whites' Reactions to Multiculturalism, 101 J. PeRsONALITY \& SOC. PSYCHOL. 337 (2011).

${ }^{198}$ STEELE, supra note 19, at 208.

${ }^{199}$ Id. at 209.
} 
each of its seven components can be achieved through the recognition of context and identity contingencies.

However, these social cues are complex. They are neither cumulative nor mutually exclusive. However, they are powerful. Purdie-Vaughns and Steele found that "when people are appraising an identity threat, one social cue can shape the interpretation of another." Some positive cues could neutralize other negative cues and make a student feel identity safe. ${ }^{200}$

Ultimately, our institutions have the power to shape our environments. They can create diversity, but they cannot create functional diversity without acknowledging the power of social cues. No amount of critical mass will cure racial misunderstanding or racial stereotyping if institutions fail to recognize that each and every student is multitasking - most especially students of color. As Steele observes, students are assessing the risk of identity threat via social cues, they are protecting against that threat, and they are trying to complete the task at hand. ${ }^{201}$ All of these of activities can exact a terrible toll on a student.

Institutions need affirmative action to create diversity that will allow for social cues that will build trust. The individual characteristics of people cannot be changed, but the meanings of their master status can. Affirmative action is the first small step in that process. The real purpose of affirmative action is to break down barriers that have accumulated institutionally and personally - to stop suppressing human potential. When courts evaluate in the future whether affirmative action is still necessary, they should look for racial equality, certainly, but also for the contextualized social contingencies that an institution has put in place to ensure identity threat is no longer relevant. And all of these cues should occur well before a student enters college. ${ }^{202}$ Only then will we have true colorblindness.

${ }^{200} I d$. at 147.

${ }^{201} I d$.

${ }^{202}$ Steele points out many programs that create powerful social cues that neutralize contigencies and build identity-safe environments. For example, he describes alternative ways to give feedback so minorities feel motivated and empowered. By removing racial isolation, you can build trust and comfort, and improve performance. By allowing elementary students to write self-affirming statements about their most important self-values, their grades can improve longtitudinally. Allowing students to create narratives that explain their frustration while creating a positive setting can radically change a student's life course. $I d$. at 216. Each of these programs provides skills to create a more powerful diverse environment with the kind of functioning Carbado and Gulati and O'Connor might envision. One of the most compelling stories Steele tells is of an experiment in which a diverse group of students meet to discuss their challenges in school. The meetings were most beneficial for students of color because they enabled the students to know that they were not alone in finding school difficult and frustrating. He tells this same story about O'Connor being the lone female on the Court. 
U N I V E R S I T Y O F P I T T S B U R G H L A W R E V I E W

PAGE

Make no mistake, my call to consider the relevance of critical mass in favor of more effective tools is not a call to abandon affirmative action. As Steele observed, no amount of neutralizing identity threat will overcome the barriers of a poor education, but equally, a great education will not overcome the deleterious effects of stereotype threats. This research suggests we have not yet overcome those stereotype threats. Affirmative action remains a first and necessary building block in this process.

As Sumi Cho put it:

We cannot abandon the salience of "societal" discrimination merely because the Court has deemed most forms of institutionalized racism to exist beyond the reach of racial remedies. We must revisit Bakke's dissent. We need a discussion of not only the broader social conditions that make affirmative action necessary, but a broader discussion of how we need to act as a society to "do right" by those who have been historically and contemporarily mistreated. ${ }^{203}$

Our goal should be to embrace diversity in its most functional form in which all students find learning and not evaluation as its key goal.

\section{Conclusion}

"[A] school's self-portrayal as [an] institution committed to racial justice amounts to little more than 'an opportunity of self-important romance' reminiscent of a 'late-night fit of drunken sentimentality. ,',204

Affirmative action provides a potentially powerful tool to do right by students of color - to build functional diversity. To do racial justice. In the end, colleges and universities must recognize that attributes of "diversity" do not operate in a vacuum. Institutions of higher learning would do well to consider why critical mass falls short for so many students of color. Instead, adopting a color-conscious approach that recognizes social identities and equips students and faculty with the skills to interact in a beneficial way for all will lead to a more honest form of affirmative action for students of all skin colors.

${ }^{203}$ Cho, supra note 76 , at 831.

${ }^{204}$ See Hutchinson, supra note 178, at 1088 (quoting Steven D. Smith, Conciliating Hatred, 144 FIRST THINGS 17, 18 (2004)). 


\section{APPENDIX A}

Survey no.

\section{Survey on the Ideal Diverse Classroom and its Benefits:}

Investigator: Deirdre Bowen, J.D., Ph.D. Email: dbowen@seattleu.edu

Instructions: This survey is 4 pages long. It will take approximately 10 minutes to fill out. The survey is completely confidential. You may stop the survey at any time or skip any questions you don't wish to answer. Most of the questions ask you to check a box, but some questions ask you to fill out a written answer.

\section{Part I: Creating a Diverse Classroom Environment}

1. If you could waive your magic wand and create a diverse classroom population, please describe its make up.

2. Have you ever been in a classroom that had your ideal diverse environment?

Yes No

3. Please describe the benefits you received or you could imagine receiving from being in a diverse classroom environment.

\section{Part II: Learning a Little Bit about You}

4. What is your gender?
Male Female Other

5. What state do you attend college or university in?

6. Do you attend: Private School State/Public School 
U N I V E R S I T Y O F P I T T S B U R G H L A W R E V I E W

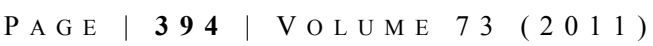

7. Do you attend a historically Black college or university?

Yes No

8. What is the highest level of education either of your parents received?

Less than high school

High school degree

Some college

9. How old are you?

10. What year are you in the program?

Freshman

Sophomore

Junior
Associates Degree

Bachelors Degree (usually a four year degree)

Graduate Degree (MA, Ph.D., J.D., M.Ed., MBA, M.S.)

11. With which racial/ethnic background do you identify?

African American/Black

Asian/Pacific Islander

Middle Eastern

American Indian/Alaskan Native

Chicano/Latina/o/Hispanic

White/Caucasian

Two or more races

12. Are you an international student?

Yes No

\section{Part III. More on Diversity}

13. In column A, please give a percentage breakdown by gender and race (including your own) of what a typical classroom population currently looks like for you.

In column B, please give a percentage breakdown by gender and race of what an ideal classroom population would look like. Feel free to use any of the categories from question 11. For example, you can write $45 \%$ (fill in gender or race/ethnic group), 25\% (fill in gender or ethnic/racial group)

A. Current classroom population

$-$\begin{tabular}{l}
$\%$ \\
$\%$ \\
$\%$ \\
\hline
\end{tabular}

B. Ideal classroom population

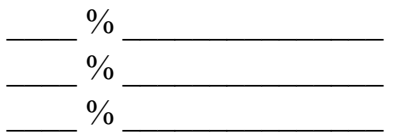




$-\left[\begin{array}{l}\% \\ \% \\ -\% \\ \% \\ \% \\ \%\end{array}\right.$

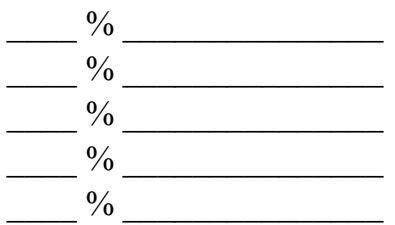

Please state whether you agree with any of the following statements, using a ranking system between one to six, 1 means that you do not agree at all and $\mathbf{6}$ means that you completely agree with the statement.

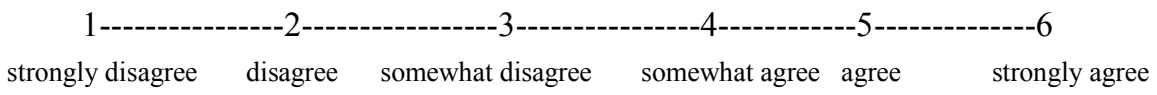

4. Being in a classroom with individuals who have a DIFFERENT racial or ethnic background or gender from my own:

a. led me to learn more in those classes.

b. promoted positive inter-racial experiences for me inside \& outside of class.

c. led me to greater understanding of others' perspectives.

d. led me to be a more motivated student.

e. made me feel more welcome on campus.

f. is important to me.

g. led to white students understanding other racial/ethnic groups' perspectives.

h. led to positive inter-racial experiences for other students inside of class.

i. decreased the amount of overt racism I encountered in class.

j. decreased the number of times others questioned my qualifications in class.

$k$. decreased the amount of pressure I felt to prove myself because of my race/ethnicity and/or gender in class.

1. led to more positive interactions with the classroom professor.

Just one more page to go! Please turn the page.

Remember, this is the rating scale

strongly disagree disagree somewhat disagree somewhat agree agree strongly agree


U N I V E R S I T Y O F P I T T S B U R G H L A W R E V I E W

PAGE

15. Being in a classroom with individuals who have the SAME racial or ethnic background or gender as my own:

a. is important to me.

b. increased my learning ability.

c. increased positive cross-racial experiences for me inside the classroom.

d. made me feel more welcome on campus.

e. led me to be a more motivated student.

f. increased my self-confidence.

g. led to white students understanding other racial/ethnic groups' perspectives.

h. led to positive inter-racial experiences for other students inside of class.

i. decreased the amount of overt racism I encountered.

j. decreased the number of times others questioned my qualifications.

k. decreased the amount of pressure I felt to prove myself because of my race/ethnicity and/or gender.

1. led to more positive interactions with the classroom professor.

Thank you for taking this survey! Please place in envelope and drop in the box! 


\section{APPENDIX B}

In conducting any research, there are constraints on what a researcher can do that lead to limitations on the conclusions drawn and to recommendations for future research. I note here both the limitations, questions, and rationales for some of the decisions made in conducting this research.

This sample is in no way representative of the general population of minority students attending college. It is an exploratory study of over three hundred underrepresented minority students from twenty-eight states majoring in the sciences. It offers some trends of how to think about the effectiveness of diversity and critical mass in light of the goals articulated in Grutter. While this study identifies whether students attended a private or public institution, being able to identify the specific institution that a student attended would allow for analysis on the varying reaction to affirmative action policies based on the competitiveness of admissions at a particular school.

In addition, knowing the specific institution would allow examination of the impact of recruitment and retention programs on student experiences; the impact of institutional cultural norms; the effect of urban, suburban or rural locations; and the consequences of economic resources at the institution on stigma and hostility.

However, data collection did allow for me to see whether a student attended an historically black college or university, which may play a significant role in their experience on campus.

Furthermore, methodologically, if a significant number of students attend the same school, nesting occurs, which could skew the results because those students reflect the unique experiences of just one institution. The small sample size also led to constraints in the nature of the type of analysis that was possible. In this study, I limited my statistical analysis to examining whether a relationship existed between the measures of stigma, the type of school where one attended, and diversity and critical mass.

Ideally, this would be just the first phase of a more complex study that would result in the development of a parsimonious model of predictors of whether one experiences decreases in stigma and under what conditions of diversity and hostility.

However, as there were only about sixty students attending anti-affirmative action schools, and data was missing on every variable, statistical power was rapidly lost, making it difficult to achieve statistical significance and detect effect size, otherwise known as the strength of the relationship between two variables.

On the one hand, the fact that a number of relationships were identified with a relatively small sample, medium effect sizes, and statistical significance, suggests 
U N I V E R S I T Y O F P I T T S B U R G H L A W R E V I E W

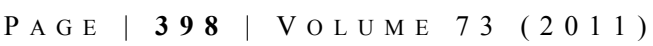

that these relationships have substantive significance too. It is equally worth noting that relationships were not found. In other words, the numerical trends tell a story worth recording in the social world. On the other hand, most of these relationships were bivariate in nature, and certain key variables were controlled, telling a more compelling story about the nature of the relationships, particularly with regard to critical mass.

Additional variables and a larger samples size could have allowed for a more robust story. For example, the story told focuses mostly on racial and ethnic groups as a whole, yet the paper acknowledges that different racial groups have very different responses to the benefits of diversity.

Finally, it is important to note that these results do not present causal connections. They reveal only associations between the Grutter benefits, diversity and critical mass, and where one attends school. The data cannot determine whether critical mass or diversity causes decreases in stigma.

Future questions might examine longitudinally how affirmative action, social cues, and contextualization play a role in decreasing stigma. In addition, how white students perceive the benefits of affirmative action would be important to examine. (I am currently collecting data on this project.) Finally, whether priming can change social cues would be important to look at, as thus far it appears to have only been explored in laboratory settings. 